Makale Geliș | Received: 05.06.20.

Makale Kabul | Accepted: 14.06.20.

DOI: 10.18795/gumusmaviatlas. 748463

Mavi Atlas, 8(2)2020: 323-342

Araştırma Makalesi|Research Article

\begin{abstract}
Ahmet YÜKSEL
Doç. Dr.|Assoc. Prof. Dr.

Sivas Cumhuriyet Üniversitesi, Edebiyat Fakültesi, Tarih Bölümü, Sivas-TÜRKIYE Sivas Cumhuriyet University, Faculty of Letters, Department of History, Sivas-TURKEY

ORCID: 0000-0001-5353-1989

ayuksel@cumhuriyet.edu.tr
\end{abstract}

\title{
İstanbul, Kahire ve Beyrut Üçgeninde Firarî Bir Osmanlı Polisi
}

Öz

Osmanlı polis müessesesinin taşrada teşkilatlanıp yaygınlaşması 1880'li yıllar itibariyle gerçekleşmiştir. Bu çalışma o teşkilatın mensuplarından birisinin son derece ilginç ve bir o kadar da heyecanı yüksek hikâyesini konu edinmektedir. I. Dünya Savaşı'nın hemen arifesinde Ali Rıza isimli ve Aydın vilayetine bağlı İzmir'de görevli üçüncü sınıf bir polis komiseri rüşvet suçlamasıyla meslekten atılınca soluğu Misır'da almıştır. Giderken beraberinde üzerine zimmetli devlet eşyalarını da götürdüğü iddiasıyla Osmanlı yönetimi, Ali Rıza Efendi'nin peşine düşmüştür. O şekilde başlayan takip amansız bir kovalamacaya dönüşmüş ve nice ilginç gelişmeyi beraberinde getirmiştir. $\mathrm{Bu}$ araştırma o takibe odaklanmakla birlikte devrin Aydın polis teşkilatına, kanunî metinler üzerinden polislik mesleğinin işleyişine ve ayrıca bazı politik olay ve şahsiyetlere dair ayrıntılar da sunmaktadır. Son olarak, yakın bir zamanda "Abdülhamid İstanbul'unda Bir Polisin Yaşamı"na ilişkin küçük ama doyurucu bir araştırma gerçekleştiren Roger A. Deal'in "Osmanlı polis çalışmalarını hızla gelişen sosyal tarih alanına kaydırarak devlet merkezli tartışmalardan uzaklaştırmak" yönünde kapısını araladığ1 arzu istikametinde bir ilerleme kaydedebilmek de bu araştırmanın ulaşmak istediği hedeflerden birisi olmuştur. Bahsedilen amaçlar doğrultusunda bu çalışmanın vücuda getirilmesi noktasında Osmanlı arşiv vesikaları başta olmak üzere Aydın polis teşkilatı ve polislik mesleğine ilişkin düzenlemeler hakkında Düstur, Salname ve Polis mecmuası gibi süreli ve resmi yayınlardan, ayrıca zaman, mekân ve insana dair araştırma inceleme türü çalışmalardan da istifade edilmiştir.

Anahtar Kelimeler: Osmanl, Polis, Aydın, İzmir, Firar, Casus.

\section{An Escaped Ottoman Police in the Triangle of Istanbul, Cairo and Beirut}

\begin{abstract}
The organization and expansion of the Ottoman police organization in the provinces took place in the 1880s. This study is about the story of one of the members of that organization, which is very interesting and exciting. On the eve of the WWI, a third-class police commissioner, an incumbent in İzmir where subordinate of the Province of Aydin, named Ali Riza took his breath in Egypt after he was unseated from his career in charge of bribery. The Ottoman administration was chasing Ali Riza, with the claim of while he was leaving that he took along the embezzled state goods with him. The pursuit started in that way turned into a relentless chase and brought along many interesting developments. Although this research focuses on that chase, it also provides details of the Aydin police organization of the period, the functioning of the police profession through law texts as well as some political events and personalities. Finally, to be able to make progress has been one of the aims of this research be the same with Roger A. Deal's research which, recently conducted a small but satisfying, on "A Policeman's Life in Hamidian İstanbul” opened a door in the direction of desire that to "move Ottoman Police work away from the state-centred discussions into the rapidly developing social history area". For the purpose of bringing this study to the body for the purposes mentioned, periodical and official publications such as Düstur, Salname and Police Magazine, as well as the studies and research studies related to time, place and people were also benefited from the Ottoman archive documents, the Aydın poliçe organization and the regulations regarding the police profession.
\end{abstract}

Keywords: Ottoman, Police, Aydın, İzmir, Breakout, Spy. 


\section{Özgeçmiş ve Polisliğe Giriş}

Bu çalışma için kaynaklık ve kahramanlık eden Ali Rıza Efendi, 1883 (1298) doğumludur. Aslen Kırkağaçlı, doğma büyüme İstanbulludur (BOA, DH. EUM. EMN., 117/28, s. 3). ${ }^{1}$ Babas1, Siroz redif taburunun dördüncü bölük yüzbaşısı Mustafa Efendi'dir. Ali Rıza, sıbyan ve rüştiye mekteplerinde eğitimini tamamladıktan sonra tahsiline Harbiye Mektebinden devam etmiştir. Ancak üçüncü sınıfta okurken II. Abdülhamid idaresine muhalif söylemlerinden ötürü mektepten atılmış ve askerliğini 1904-1909 yılları arasında bir nefer olarak tamamlamak mecburiyetinde kalmıştır. Askerden sonra memuriyet hayatına atılmış, Pirlepe'de (Makedonya) tahsilat kâtipliği yapmıştır. Ancak kısa bir süre sonra istifa ederek İstanbul'a dönmüştür. Dayısının, Fatih Yeni Çeşme'de bulunan 8 numaralı evinde misafir olarak kaldığı günlerde polislik mesleğine girebilmek için Zaptiye Nezareti'ne dilekçeyle müracaatta bulunmuştur. II. Abdülhamid rejimini sert bir dille eleştiren, Meşruti idareyi aşırı öven ifadelerle bezeli 12 Mayıs 1909 tarihli o dilekçesi birazdan tanıklık edilecek olan nizama aykırı ve aşırı abartılı yükselişine tesir etmiş olabilir. Çünkü dikkat çekilen ifade tarzının yanında Harbiye Mektebinde yaşadığı mağduriyeti de dilekçesinde işlemeyi ihmal etmemiştir. Öte taraftan tenkit ettiği o idare zamanında bir Liyakat madalyası almış olduğunu da... Kendi deyimiyle esasında yegâne arzusu bir polis memuru olarak devlet ve milletine hizmet edebilmektir. Başvuru yaptığı sırada 26 yaşındadır ve 1907 Polis Nizamnamesi’nin polisliğe müracaat edebilmek için 25 yaşını doldurmuş olma şartını (Düstur 8, Tertib-i evvel: 669) hâlihazırda sağlamıştır. Nizamnamenin şart koştuğu diğer vasıfları taşıyıp taşımadığı ise yapılacak tahkik ve tetkikler neticesinde anlaşılacaktır. Bunun için dilekçesinin havale edildiği İstanbul Polis Müdüriyeti, Ali Rıza hakkında hayli geniş çaplı bir araştırma başlatmışır. İlkin mahalle sakinlerine müracaat edilmiş; onlardan Ali Rıza Efendi’nin dürüst ve namuslu birisi olduğunun, kumar ve içki gibi kötü alışkanlıklardan uzak durduğunun, hatta mahalle kahvesine bile çıkmadığının herkesçe malum olduğu yönünde bir cevap alınmıştır (EGM Özlük Dosyaları: C-1557).

Fatih Polis Merkezi de kendisine verilen emre uygun olarak Ali Riza hakkında hem olağan hem de hususî bir tahkikat yürütmüştür. Neticesinde oluşturulan raporlar mahalle sakinlerini doğrular niteliktedir: "Ali Rıza'nın polis mesleğine kabulünü engelleyici hiçbir hali bulunmamaktadır." Ayrıca söz konusu özel raporda -şimdiye kadar aktarılanlardan farklı olarak- Ali Rıza’nın bekâr olduğu, II. Abdülhamid ve adamlarına intisabı olmadığı ve hafiyelik etmediği, son 78 aydır da dayısının yanında kaldığı gibi bilgilere yer verilmişti. Sabıka kaydının da temiz çıkmasının ardından Ali Rıza sağlık kontrolünden geçirilmiş ve polislik mesleğini yapmasına engel herhangi bir hastalık veya sakatlığının olmadığı anlaşılmıştır. Bütün bu raporlar, ayrıca dilekçesine iliştirdiği diploma ve aşı şahadetnamesi gibi 1907 Polis Nizamnamesi'nin şart koştuğu vesikalar incelendikten sonra uygunlukları onaylanmış ve nihayet Ali Rıza bir imtihana tabi tutulmuştu. Bu kapsamda kendisinden bir vaka örneği ve rapor kaleme alması istendi. İmtihan bittiğinde sınav evrakının üzerine düşülen not "yeterli derecede ehliyeti olduğunun anlaşıldığı" yönündeydi. Bu şekilde 21 Haziran 1909 tarihi itibariyle polisliğe kaydı yapıldı ve akabinde Dersaadet Polis Mektebi'ne kabul edildi. Böylece Ali Riza Efendi 14 Temmuz-11 Kasım 1909 tarihleri arasında 3 ay 28 gün süren Dersaadet Polis Mektebinin ilk eğitim-öğretim dönemine (Şahin, 2018: 269) dâhil edilerek mektebi ala derecede diploma (şahadetname) ile bitirme başarısı gösterdi. Başarının ödülü 300 kuruş maaş ile İstanbul 1014 numaralı polis memurluğuna tayin edilmek oldu (EGM Özlük Dosyaları: C-1557).

\footnotetext{
1 Polisliğe müracaatı kapsamında yapılan tahkikat neticesinde oluşturulan raporda memleketi (İstanbul), doğduğu yıl (1300) ve yer (Aydın Vilayeti'nin Kasaba (Turgutlu) Nahiyesi) için, hatta fiziksel özellikleri hakkında farklı bilgilere yer verildiği görülmüştür. Bu durumun tahkikat kapsamında mahalle sakinlerinden edinilen ve daha çok onların hatırlarında kalan bilgilerden hareketle oluşturulmuş olmasından kaynaklandığı düşünülmektedir. (EGM Özlük Dosyaları: C-1557). Bu dosyaya ulaşabilmemizi sağlayan Türk polis tarihinin emektar ve çalışkan kalemlerinden Emniyet Genel Müdürlüğü Eski Arşiv Daire Başkanı, Emekli 1. Sınıf Emniyet Müdürü Eyüp Şahin Beyefendi’ye teşekkürü bir borç biliriz.
} 


\section{Ali Rıza Efendi'nin Meslekteki Hızlı Yükseliş ve Düşüşü}

Ali Rıza Efendi, yukarıda aktarılan süreç sonunda artık Osmanlı Emniyet teşkilatının bir mensubu olmuştu. Bundan sonraki süreç Ali Rıza için galiba kendisinin de tahmin edemeyeceği hızlı bir yükselissi beraberinde getirdi. Polisliğe adım atışının üzerinden henüz birkaç ayın geçtiği 13 Şubat 1910 tarihi itibariyle İstanbul Langa mevkii 157 numaralı komiser muavinliğine imtihanla ve 600 kuruş maaşla terfi etmişti. (EGM Özlük Dosyaları: C-1557). Bu hızlı yükselişte yadırganacak bir durum yoktur. Çünkü 1907 Nizamnamesi'ne göre, komiserlikler için ehliyet ve kıdem erbabından olanların İdare komisyonları huzurunda 32. maddede gösterilen şartlara uygun olarak imtihanları icra ediliyordu ve İdare meclisleri tarafindan gerekli tetkikler yapıldıktan sonra ehliyetini en iyi şekilde ispat edenler seçiliyordu (Düstur 8, Tertib-i evvel: 671). Oysa 1913 Polis Nizamnamesi terfi için bir simfta en az iki ynl bižmet etmek (Düstur 5, Tertib-i sani: 388) şartını getirecektir.

Nizamnameye uygun söz konusu yükselişin ardından Ali Rıza başkentten hayli uzakta yeni bir terfie konu olacaktır. Bu gelişmeye imza atan isimse -şimdilik- teşkilatın en tepe isimlerinden İstanbul Polis Müdürü Azmi Bey'dir. Kendisi 28 Temmuz 1910 tarihinde Emniyet-i Umumiye Müdüriyetine gönderdiği bir yazıda Ali Rıza Efendi'nin polislik vazifesindeki faaliyet ve ciddiyetine, ayrıca duyulan gerekliliğe dikkat çektikten sonra onun ikinci komiserlikle Beyrut vilayetine nakledilmesine izin verilmesini istirham etmişti. Beyrut vilayeti ile yapılan görüşmeler neticesinde tayinde bir sakınca görülmemiş, Ali Rıza'nın 14 Eylül 1910 tarihinde 750 kuruş maaşla ikinci komiserliğe terfi ettirilip Beyrut'a gönderilmesi ve Trablusşam'da istihdam edilmesi kararlaştırılmıştır. (EGM Özlük Dosyaları: C-1557). Nitekim 10 gün sonra (24 Eylül) Trablusşam Mutasarrıflı̆̆ından Beyrut Polis Müdüriyetine bildirildiği üzere Ali Rıza İstanbul'dan gelip vazifesine başlamıştır. Durum, 5 Ekim 1910 tarihinde Beyrut Polis Müdürü Cemal Bey tarafindan Emniyet-i Umumiye Müdüriyetine aktarıldıktan sonra Ali Rıza Efendi’nin kayıt işlemleri Vilayet Muhasebe Dairesi tarafından icra edilmiştir. Böylelikle Ali Rıza, bir yıl gibi kısa bir süre içerisinde, belki komiser muavinliğini dahi hayal edemezken -üçüncü sınıfı hiç uğramadan atlayıp- birdenbire isminin önüne ikinci sınıf polis komiserliği unvanını yazdırmıştır. Ancak Ali Rıza Efendi'nin düşüşü de tıpkı yükselişi gibi pek hızlı olacaktır. Cemal Bey’in ardından Beyrut Polis Müdüriyetine atanan Hüsnü Bey yaptığı incelemeler sırasında Ali Rıza Efendi'nin komiserlik vazifesine nizamî usuller dairesinde tayin edilmemiş olduğunu fark etmiş ve durumu 4 Nisan 1911 tarihinde Emniyeti Umumiye Müdüriyetine bildirmiştir. Onun ifadesiyle Ali Rıza Efendi’nin söz konusu komiserliğe terfi edebilmesi, Polis Nizamnamesi'nin 26. maddesinde (Düstur 8, Tertib-i evvel: 671) belirtildiği üzere yazılı intihap evrakının tetkikinden sonra intihap durumunun tasdikine bağlıdır. Oysa Ali Rıza için Heyet-i İntihabiye muamelesinin yapılmamış olduğu Polis Meclisi derkenarından anlaşılmıştır. Ayrıca Vilayet İdare Meclisi tarafindan da bu hususta herhangi bir işlem yapılmadığı görülmüştür. Dolayısıyla bu görüntü altında Ali Rıza Efendi, usulen intihap edilmemiş bir durumda kalmıştır. Dahası kendisinin bazı uygunsuz hallerinden dolayı Trablus'ta kalmasının uygun olmadığına kanaat getirilerek 25 Şubat 1911 tarihli bir yazıyla merkez vilayete gönderilmiştir. Liva tarafindan terfie layık görülmediği gibi merkez vilayete gönderilmesi de memnuniyetsizlik yaratmıss, inzibat memurları için gereken güzel vasıfları taşımadığı ve alt kademedeki memurlara karşı amirlik vazifesini yapamayacağı tecrübelerle anlaşılmıştır. Bütün bu sebeplerden ötürü terfie kesinlikle layık değildir. Esasen İstanbul mürettebatından olduğu için de 4 Nisan 1911 tarihi itibariyle Beyrut ile alakası kesilerek İstanbul'a iade edilmiştir (BOA. DH. EUM. MH., 48/37-2; 22 Mart 1327/4 Nisan 1911). Emniyet-i Umumiye Müdüriyeti Muhasebe Kaleminden Beyrut Polis Müdüriyetine gönderilen bir yazıyla İstanbul komiser muavini Ali Rıza Efendi'nin geri dönme sebebi ile

\footnotetext{
2 Ali Rıza Efendi’nin meslekte istihdam edildiği yıllarda yürürlükte olan 1907 Polis Nizamnamesi’nin 8. maddesi polisleri meslekî dereceleri açısından beş sınıfa ayırmıştı: Serkomiser (başkomiser), ikinci komiser, üçüncü komiser, komiser muavini ve polis memuru (Düstur 8, Tertib-i evvel: 667). 1913 Nizamnamesi'nin 7. maddesiyle ise polis silsilesi aşağıdan yukarıya doğru polis namzedi (aday), polis memuru, komiser muavini, ikinci komiser ve serkomiser şeklinde bir sinıflandırmaya tabi tutulmuştu (Düstur 5, Tertib-i sani: 385-86).
} 
dönüşünde harcırah alıp almadığının bildirilmesi istenmiştir. Beyrut Polis Müdürü Hüsnü ise 5 Nisan 1911 tarihli cevabında, Ali Rıza Efendi’nin Trablusşam'a ikinci komiserliğe intihap edilmek üzere gelmiş olduğunu, ancak intihabının mümkün olamayışından dolayı İstanbul'a döndügünü, ayrıca Beyrut'ta harcırah için ayrılan bütçenin tamamen harcanmış olmasından dolayı kendisine dönüș harcırahı verilemediğini arz etmiști (BOA. DH. EUM. MH., 48/37-4; 23 Mart 1327/5 Nisan 1911). Böylece Ali Rıza Efendi'nin meslekî yaşantısındaki Trablus ve ikinci komiserlik sayfası muhtemelen kendisinin de bir daha açılmasını istemeyeceği kadar gurur kırıcı bir sonla kapanmıştır. ${ }^{3}$

\section{İzmir: Meslekte Son Durak mi?}

Yaşanan son gelişmelerin ardından Osmanlı başkentine dönen yahut daha doğru bir ifadeyle Beyrut'tan kovulan Ali Rıza Efendi için ümitsizlik yoktur. Çünkü onun hamileri olduğu muhakkaktır. Şayet öyle olmasaydı, Jön Türk tensikatı sonrası açığa alınan ve Emniyet teşkilatının kapısında yeniden göreve tayin edilecekleri anın gelmesini bekleyen bir yığın işsiz polis varken Ali Rıza Efendi için hemen yeni bir atama kararı çıkabilir miydi? Üstelik Ali Rıza'nın yeni durağı o gün itibariyle doğduğu toprakları da kapsayan Aydın Vilayeti olabilir miydi? Elbette zordu, ancak Ali Rıza için şimdilik öyle bir durum söz konusu bile değildir. Kendisi 22 Nisan 1911 tarihinde, yani bir ay bile açıkta kalmadan 600 kuruş maaşla -ancak- bu kez üçüncü sınıf komiserliğe naklen tayin edilmiştir (EGM Özlük Dosyaları: C-1557). Vilayet içerisinde ise merkez sancak konumundaki İzmir'de görevlendirilmiştir. Ali Rıza'nın hikâyesinde sonun başlangıcı olması münasebetiyle arz ettiği önem ve görüntü açısından vilayet polis teşkilatının durumuna kısaca temas etmek faydalı olacaktır. En yakın tarihli ve sonuncu olan 1908 (H. 1326) Aydın Vilayet Salnamesi'ne göre vilayette görevli polis memurlarının sayı ve rütbeler itibariyle dağılımları şu şekildedir:

\begin{tabular}{|c|c|c|c|c|c|c|c|}
\hline \multirow[b]{2}{*}{ Sancaklar } & \multicolumn{6}{|c|}{ Memuriyet Dereceleri } & \multirow[b]{2}{*}{ Toplam } \\
\hline & Müdür & Müfettiş & $\begin{array}{c}\text { Ser } \\
\text { Komiser }\end{array}$ & $\begin{array}{c}\text { İkinci } \\
\text { Komiser }\end{array}$ & $\begin{array}{l}\text { Üçüncü } \\
\text { Komiser }\end{array}$ & $\begin{array}{c}\text { Polis } \\
\text { Memuru }\end{array}$ & \\
\hline İzmir & 1 & 1 & 7 & 16 & 39 & 186 & 250 \\
\hline Saruhan & - & - & 1 & 2 & 9 & 14 & 36 \\
\hline Aydın & - & - & 1 & - & 5 & 10 & 16 \\
\hline Denizli & - & - & - & - & 6 & 8 & 14 \\
\hline Manisa & - & - & - & - & 4 & 10 & 14 \\
\hline Toplam & 1 & 1 & 9 & 18 & 63 & $228^{4}$ & 320 \\
\hline
\end{tabular}

Aydın vilayetindeki polis sayısı 1910 ylında 355 olarak tespit edilmiştir (Lévy-Aksu, 2017: 232). 1914 yll itibariyle 3 liva ve 36 kazayı kapsayan vilayette 3 ikinci sinıf komiser, 17 komiser muavini ve 110 polis memuru mevcuttur. Onlardan ikinci sinıf komiserlerle 2 muavin ve 38 polis memuru liva merkezlerinde, geriye kalan 15 muavinle 72 polis memuru ise kaza merkezlerinde istihdam edilmişti. Vilayette mevcut 16 karakolun dişında kira yoluyla faaliyet gösteren 12 karakol daha vardı. Ancak vilayetin büyüklüğüne kıyasla karakollar sayı açısından yetersizdi. Fizikî durumları ise ödenek eksikliği nedeniyle içler açısı bir vaziyetteydi. Birçoğu sağlığa elverişsiz, döşemeden mahrum, ışıklandırma ve ısınma konularında hayli eksik bir durumdaydılar. ${ }^{5}$ Aydın Polis Müdürü

\footnotetext{
3 Ali Rıza Efendi’nin Trablusşam Komiserliği’nde istihdam edilmiş olduğu dönemde kendisiyle alakalı bir vesikaya tesadüf edilmiştir. Trablusşam Sancağı Polis Dairesi'nin 1909 mefruşat masrafı hakkında düzenlenen o belgede Ali Rıza sadece ismen geçmektedir. Bu nedenle o polisin bu araştırmanın konusu olan Ali Rıza Efendi olduğuna hükmedebilmek güçtür. (BOA, DH. EUM. MH., 122/71).

${ }_{4}^{4}$ Salnamede yanlış bir hesaplamanın neticesi olarak bu rakam 226 olarak kaydedilmiş, ancak genel toplam içerisinde o yanlışlık giderilmiştir.

5 Başlangıçta mevcut olan Servili Mescit, Pasaport, Fasulya (Facciola), Namazgâh, Çalgıcıbaş1, Göztepe, Peştemalcılarbaşı, İkiçeşmelik, Keçeciler, Aziziye, Dolaplıkuyu, Hamidiye karakollarına daha sonra Kemeraltı, Kemer ve Çorakkapı gibi yeni karakollar eklenmişti. Kiralanan karakollar arasında Göztepe Polis İdaresi dairesinin dışında,
} 
Cemal Bey'in 14 ay kadar devam eden hizmet süresi boyunca yaptığı gözlemlerine dayalı olarak 1913 Nisan'ında kaleme aldığı rapor niteliğindeki uzunca bir yazıdan vilayetin polis teşkilatına ilişkin daha ayrıntılı bilgiler edinebilmek mümkündür (Arslan, 2008: 112; Sürgevil, 1984: 43; Ar1, 2017: 435-449).

\section{1. İzmir’de Peştamalcı(lar)başı Merkezine Bağlı Tepecik Mevki Karakolu (1914)}

\section{(Polis Mecmuas1 16: 376)}

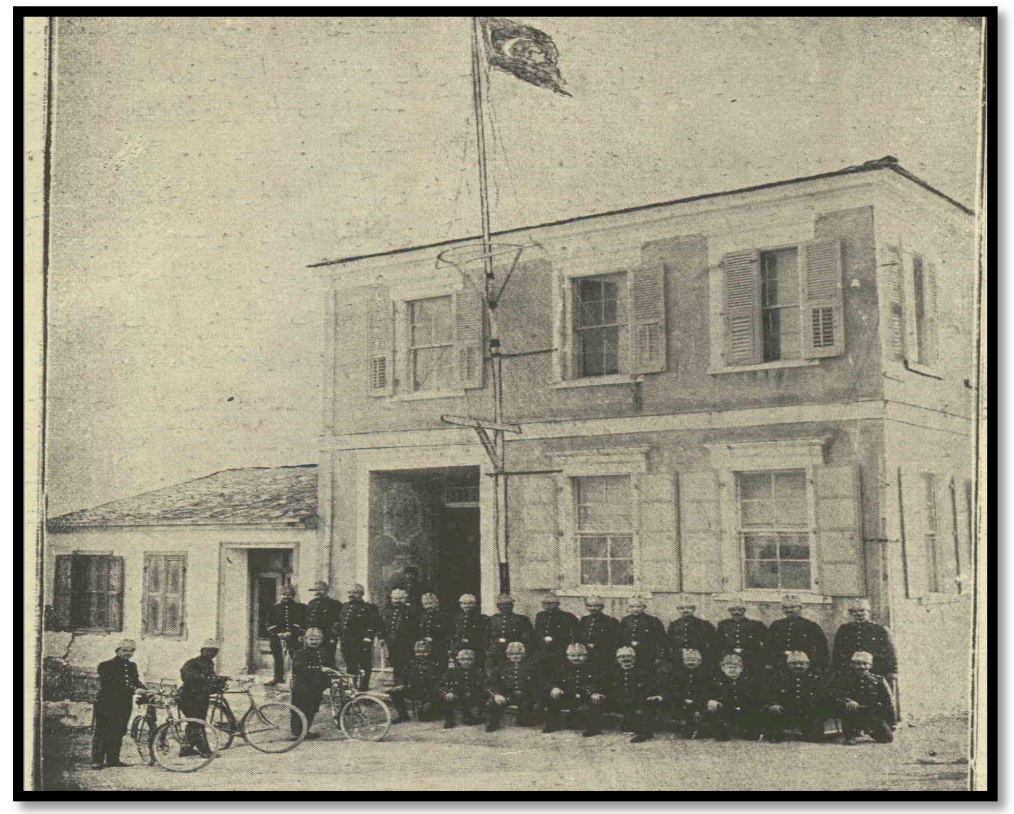

Bahsedilen polis teşkilat ve karakollarından birisinin mensubu olan Ali Rıza Efendi, aynı zamanda üçüncü sınıf komiserliğin imparatorluktaki son temsilcilerindendir. Çünkü onun meslekten atılmasindan kısa bir süre sonra yürürlüğe giren 1913 Polis Nizamnamesi ile üçüncü komiserlik kaldırıldı. Buradan tasarruf edilecek parayla her vilayete serkomiser, bazı vilayetlere de merkez memuru atanacak; mevcut ikinci komiserlerle muavinlerin maaşları, ayrıca ikinci komiserlerin sayısı artırılacaktı. Aktif görevde bulunan üçüncü sınıf komiserlerin ise mevcut maaşlarıyla kıdemli komiser muavini unvanı verilerek istihdam edilmeleri, onlardan boşalan kadrolara da yeniden atama yapılmaması kararlaştırıldı (Alyot, 2008: 506; Van, 2012: 115). Kısacas1 Ali Rıza Efendi ihraç olayı ile karşı karşıya kalmasaydı meslekî yaşantısına -en azından belirli bir süre için- kıdemli komiser muavini olarak devam edecekti.

\section{Olay ve Örüntü: İzmir'den Misır'a Savrulmak}

Ali Rıza'nın ani düşüş, ama daha çok yükselişlerle geçen meslekî yaşantısının ardından nihayet böyle bir araştırmanın gerçekleștirilmesini teşvik eden ve son derece net bir görüntü arz eden "olay örgüsü” kısmına gelindi. Yukarıda yer yer perdesi aralanan o olaylar zincirinin ilk halkası Ali Rıza Efendi'nin İzmir'de üçüncü sınıf polis komiserliği vazifesini yürüttüğü sırada "efrad-1 redifeden” rüşvet aldığının kesinleşmesiyle başlıyor (BOA, DH. KMS., 3/33, s. 5; 1 Nisan 1330/14

\footnotetext{
Tepecik, Karşıyaka, Çalıkçıbaşı, Çayırlıbahçe, Buca, Karantina, Çorakkapı ve Sarayköy karakolları ve Süvari Ahırı vardır (Arslan, 2008: 112, 117, 129, 141-142).

${ }^{6}$ Burada kullanıldığı şekliyle "redif” tabiri Muallim Nâcî tarafindan "birinin ardı sıra giden, arkadan gelen kimse, hizmeti nizamiyeden sonra geçilen sınıf (sınıf-1 redif, efrâd-1 redife, müddet-i redife, hizmet-i redife) şeklinde tanımlanmıştır (Lugat-1 Nâcî: 435). Kurumsal olaraksa "fiilî ve muvazzaf ordunun yedeği”" (ihtiyatî kuvvet) manasında kullanılmıştır. Hatırlanacağı üzere Osmanlılardaki bu yedek kuvvetler, Yeniçeri Ocağı'nın kaldırılmasından (1826) sonra Asâkir-i
} 
Nisan 1914) ve alabildiğine hareketli ve heyecanlı bir biçimde devam ediyor (BOA, DH. EUM. EMN., 117/28, s. 13; 15 Teşrinevvel 1329/28 Ekim 1913).

Esasında "polis memuru, suç ve ihraç" o günlerde Aydın vilayetinde sıkça karşılaşılan bir üçgene dönüşmüştü. Polis memurlarında görülen itaatsizlik nedeniyle Aydın Vilayet Polis Müdürü Mehmed Bey açığa alınmış, yerine Emniyet-i Umumiye müfettişlerinden Cemal Bey tayin edilmişti (1911 yılı başları). Kendisine yüklenen vazife son derece mühimdi. Çoğunun ahlaksız ve iktidarsız olduğuna dair sürekli olarak devlet merkezine ihbar edilen vilayetin polis memurları hakkında gerekli tahkikatı yapıp tedbirleri alacaktı. Bu kapsamda Cemal Bey tarafindan yürütülen araştırmalar neticesinde hazırlanan rapor Ali Rıza Efendi'nin işlediği suçun bir bulaşıcı hastalık gibi toplumun emniyet ve asayişinin teminatı demek olan memurların çoğuna sirayet etmiş olduğunu gözler önüne seriyordu: Rüşvet, fuhuş, serkeşlik gibi yasadışı eylemlere karışan ve görevini kötüye kullanan memurların çoğu isimleriyle birlikte ifşa edilmiş ve haklarında gerekli cezaî işlemler yapılmıştı (Arslan, 2008: 123-126). Bu gelişmeyi o devirdeki polisin resmî yayın organlarından da takip edebilmek mümkündür. Mesela Polis Mecmuası'nda yer alan habere göre 24 Haziran 1913 ile 13 Aralık 1913 tarihleri arasındaki 6 aylık zaman zarfında rüşvet, kaçakçılık, görevde ihmal, yetkide ihlal gibi nice sebepten ötürü Aydın Polis Müdüriyeti Polis Divanı tarafindan 42 polis memurunun kaydı silinmişti. Bu memurlar ve işledikleri suçlar tek tek listelenmiş, (Polis Mecmuası 12: 287-288) mecmuanın bir sonraki sayısında da ibret ve hayret dolu ifadelerle yorumlanmıştı (Polis Mecmuas1 13: 291-292). Başkentteki polis memurlarının 300, taşradakilerin ise 200 kuruş gibi son derece düşük ve düzensiz olarak ödenen maaşlarının onları daha iyi ve dürüst bir hizmete teşvik etmek için II. Meşrutiyet Dönemi'nde 400 kuruşa çıkarılmış olmasının ${ }^{7}$ da en azından Aydın örneğinde arzu edilen neticeyi vermediği ve rüşvet gibi kötü bir alışkanlığın artarak devam ettiği gözlemlenmektedir.

Cemal Bey'in önceki dönemlerin alışlageldik bir uygulamasına dönüştüğü aşikâr olan polisin yasadışı eylemlerini görmezden gelme yahut geçiştirme gibi bir davranış biçimi yerine onların üstüne gitme ve önünü kesme yönünde estirdiği adalet rüzgâr1 Ali Rıza Efendi'yi hem işinden hem yerinden etmişti. Vesikaların diliyle Ali Rıza, hakkındaki rüşvet iddiaları 23 Ocak 1913 tarihi itibariyle kesinleşince artık İzmir'de kalıp hizmet edemeyeceğini anlamış ve çareyi o senenin 12 Haziranı'nda İskenderiye'ye firar etmekte bulmuştu. (BOA, DH. EUM. EMN., 117/28, s. 13; 15 Tessrinevvel 1329/28 Ekim 1913). Özlük dosyasında yer alan belgelerde Ali Rıza'nın memuriyetini terk ederek Hidiviye Kumpanyası'nın Osmaniye vapuruyla İskenderiye'ye firar eylediğinin anlaşılması üzerine kaydının söz konusu tarihten (12 Haziran) itibaren silinmiş olduğu kaydedilmiştir (EGM Özlük Dosyaları: C-1557).

\section{Devlet ve Polis}

Sıradan bir memurun o şekilde sırra kadem basması, I. Dünya Savaşı'nın arifesinde bir yığın problemle kuşatılmış Osmanlı İmparatorluğu'nu yönetenlerin cephesinden herhalde pek bir anlam ifade etmemiş olmalıdır şeklinde düşünülebilir. Ancak Mısır ve İstanbul arasında başlayan yazışma trafiği köprünün altından çok sular akacağının ilk habercisi olmuştur. Osmanlı yöneticilerinin iddiasına bakılırsa Ali Rıza Efendi firar etmeden evvel devletin üzerine zimmetlemiş olduğu giysi ve silahını Aydın Polis Müdüriyetine teslim etmeyip beraberinde götürmüştür. Konuyla alakalı belgelerin ifadesiyle hiç olmąssa (BOA, DH. EUM. EMN., 117/28, s. 13; 15 Teşrinevvel 1329/28

\footnotetext{
Mansûre-i Muhammediyye adıyla olușturulan yeni orduya destek sağlamak ve halkı uzun süreli bir mecburî hizmette tutmadan kendi bölgelerinde eğiterek iç güvenliği tesis etmek amacıyla "Redîf-i Asâkir-i Mansûre veya Asâkir-i Redîfei Mansûre" adıyla oluşturulmuştu. İşte bu ordunun erleri için "efrâd-1 redîfe" tabiri kullanılırdı. Daha fazla bilgi için bkz. (Özcan, 2007: 524-526).

7 Yapılan zamlarla ayrıca merkez memurlarına 1500, komiserlere 1000 ve komiser muavinlerine de 600 kuruş maaş bağlanmasına karar verilmişti (Van, 2012: 34-35). 1914 senesinde ise İstanbul polisleriyle İzmir, Beyrut, Kudüs ve Suriye gibi birimlerin sahil kısımlarında istihdam edilen polis memurlarının maaşları yapılan 100'er kuruş zamla 500 kuruşa çıkarılmıştı. Polis maaşları için (Gören, 2018: 16-35; Şahin, 2019: 13).
} 
Ekim 1913) onların geri alınabilmesi için Ali Rıza Efendi'nin yakalanması şarttır. 1907 Polis Nizamnamesi'nin 41 ve 42. maddelerine göre "memurlar kendilerine verilen elbise, silah ve diğer eşyaları muhafaza etmek ve iyi kullanmak, meslekten ayrılmaları durumunda ise iade etmek zorundaydılar." (Düstur 8, Tertib-i evvel: 672-673.). ${ }^{8}$ Şayet iddialar doğru ise Ali Rıza Efendi o şekilde nizamnameyi ihlal etmiş oluyordu. Ancak takip eden olayların akışına bakılınca gerçekte bahsedilen gerekçenin sadece madalyonun görünen yüzü olduğu anlaşılmaktadır. Görünmeyen kısmında ise Ali Rıza Efendi'nin yakalanmasını gerektirir daha mühim sebepler vardır. En basitinden Misır'a firar etmiştir mesela. Misır ki o dönemde, A. Birinci'nin deyimiyle İttihat ve Terakki mubalefetinin (...) ilk ve en kalabahk durağın teşkil ediyordu. (Birinci, 2002: 14) Hürriyet ve İtilaf Fırkası'nın kurucu ve üyeleri gibi, İttihatçılara muhalif olup takibe uğrayanların çoğu soluğu tam da o günlerde Mısır'da alıyordu. Ali Rıza Efendi de İttihatçılara ve politikalarına karşı olanların yanında saf tutup muhalefet zincirinin yeni bir halkası olmaya soyunabilir miydi acaba? Meslekten atılmış, memleketinden hayli uzakta kalmış bir polis memuru için cazip olmayan bir tarafi yok gibi...

Aşağıda yaşanacak olan gelişmeleri daha iyi idrak ve takip edebilmek açısından ve de hazır söz açılmışken Kavalalı Mehmed Ali Paşa'nın torunları elinde heder olan Mısır'n şöyle kuşbakışı bir görüntüsünü aktarmak faydalı olacaktır. O günlerde muhaliflere kol kanat gerdiğine dikkat çekilen Mısır, hâlihazırda resmen ve hukuken Osmanlı İmparatorluğu'na bağlıydı. Anımsanacağı üzere Sultan II. Mahmud ile asi valisi arasında yaşanan birçok boğuşmanın ardından gelen uluslararası müdahale neticesinde Tanzimat Devri'nin hemen başında yayınlanan 1841 Fermanı ile Mısır'da, Kavalalı Mehmed Ali Paşa'nın soyundan gelen erkek evlatların "Hidiv" unvanıyla hükümran olacağı irsî bir valilik yönetimi oluşturulmuştu. Ancak o çok bilinen ve ağırlık merkezini ekonomik sebeplerin oluşturduğu 1882 İngiliz işgaliyle Misır hukuken olmasa da fiilen Osmanlı İmparatorluğu'nun bir parçası olmaktan çıkmışt1. Artık kendisine ait bir yönetim düzeni vardı. 24 Ekim 1885 tarihinde imzalanan bir antlaşmayla İngiltere ve Osmanlı İmparatorluğu'nun Hidiv'e danışmanlık yapmak için Mısır'da birer Yüksek Komiser bulundurmaları kabul edilmişti. Ancak kısa bir süre sonra Mısır Dışişleri Kahire'deki İngiliz Yüksek Komiserliği tarafindan idare edilmeye başlanmıştı (Polat, 2013: 53; Özkoç, 2013: 244-245). Misır'ın İttihat ve Terakki'ye muhalif olanlar, hatta onun da ötesinde diş bileyenler için bir sığınağa dönüşmüş olması İngiliz güdümüne girmiş olmasıyla alakalıydı. Özellikle I. Dünya Savaşı'nın hemen arifesinde, yani bu çalışmaya konu olan olayların yaşandığı dönemde (1913-1914) İttihatçıların Almanya ile olan yakınlaşması onlara muhalif olanlar için İngiliz himayesindeki Mısır'ı daha korunaklı ve destekli bir cazibe merkezi haline getirmişti. İlerleyen satırlarda bahsedilen görüntüyü daha net bir biçimde yakalayabilme imkânı vardir.

\section{Takip Yerelde Başliyor}

Mısır'ın arz ettiği söz konusu görüntüye ve İstanbul-Kahire arasındaki karş11lklı güvensizlikten kaynaklanan aşağıda karşılaşılacak çarpıklıklara rağmen eskinin komiseri Ali Rıza Bey'i ele geçirme amaçlı takip faaliyetleri ilkin yerel yöneticilerce başlatılmıştır. Onları harekete geçiren saik ise üzerinde bulunduğundan bahsedilen bravnik (browning) marka beylik revolverini Osmanlı İmparatorluğu'nun malzeme ofisine geri kazandırabilmek ümididir. Bu ümitle İzmir’in bağlı olduğu Aydın Valiliği tarafindan Ali Rıza Efendi'nin İzmir Polis Dairesinde bulunan fotoğrafinın bir kopyası çıkarttırılarak İskenderiye Muhafızlığına gönderilmiştir. (BOA, DH. EUM. EMN., 117/28, s. 13; 15 Teşrinevvel 1329/28 Ekim 1913).

\footnotetext{
8 Ali Rıza Efendi'yi bağlamamakla birlikte polis memurlarına devlet tarafından verilen giysi ve silah türünden malzemeler 1913 Polis Nizamnamesi ile daha ayrıntılı bir biçimde düzenlenmiştir (Düstur 5, Tertib-i sani: 402 vd).
} 


\section{Ali Rıza'nın Fotoğrafı ve Fotoğrafın Arka Yüzü}

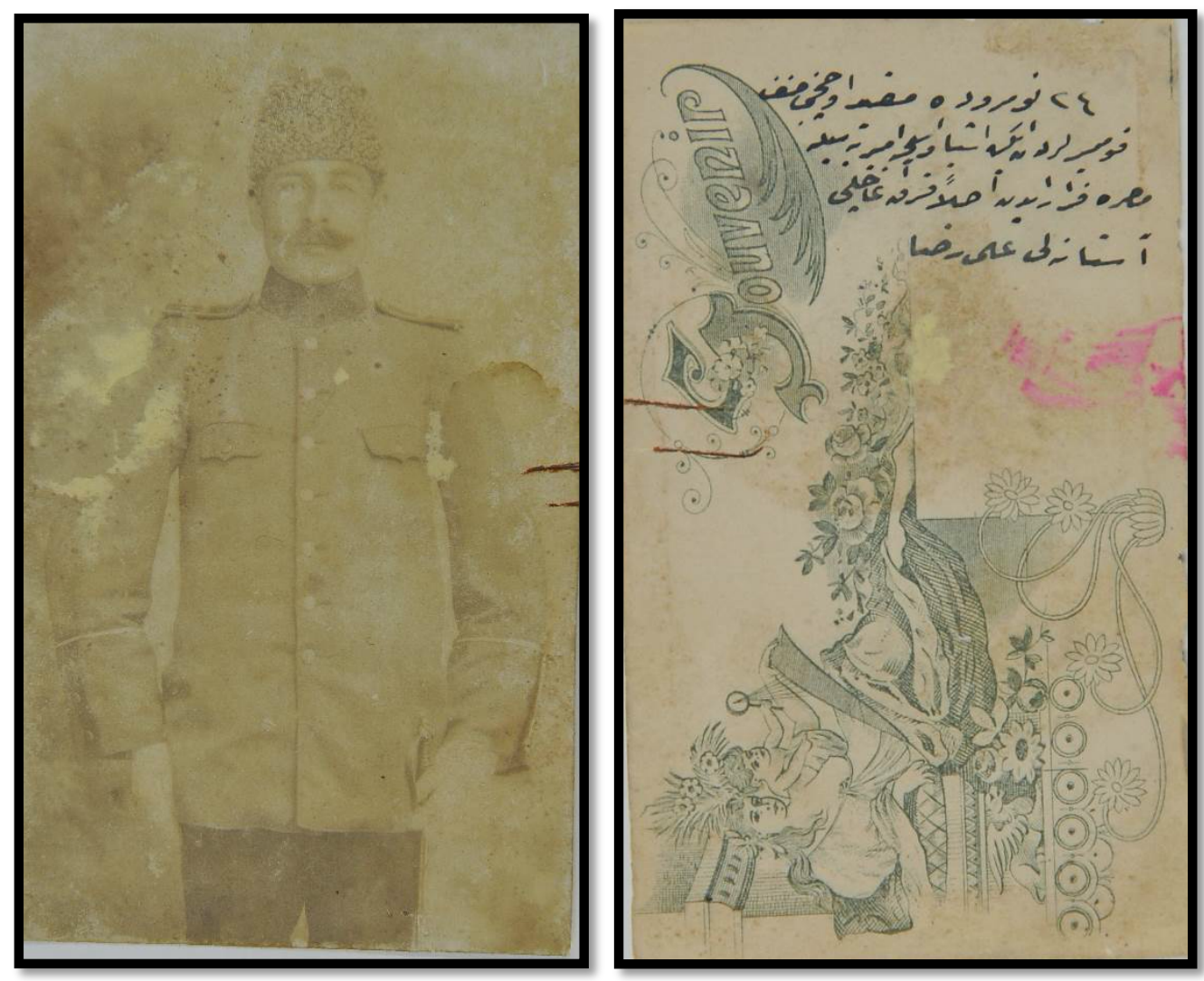

Fotoğrafin arkasina işlenen notta "24 numarada kayıtlı üçüncü sınıf komiserlerden iken devletin eşya ve silahıyla birlikte Mısır'a firar eden aslen Kırkağaçlı olan İstanbullu Ali Rıza" yazmaktadır (BOA, DH. EUM. EMN., 117/28, s. 3). Bu fotoğrafa ilaveten "İzmir polis komiserliğinden atılan" şeklinde bir tanımlamayla birlikte Ali Rıza Efendi’nin eşkâli ayrıca yazılı olarak da tasvir edilmiştir: Kendisi uzun boylu, sarı benizli, sarı bıyıklı, mavi gözlü ve otuz-otuz üç yaşlarındadır (BOA, DH. EUM. EMN., 117/28, s. 5). ${ }^{9}$ Eşkâl demişken sicil dosyasında boyunun $1,80 \mathrm{~cm}$ olduğu, herhangi bir alamet-i farikasının bulunmadığı, ayrıca fotoğraftan da anlaşılacağı üzere sakalsız olduğu kaydedilmiştir (EGM Özlük Dosyaları: C-1557).

Aydın Valiliğinden kendilerine ulaşan talep üzerine İskenderiye Muhafızlı̆ğ tarafindan şehirde başlatılan arama çalışmaları kısa bir süre içerisinde netice vermiş ve Ali Rıza Efendi'ye ulaşılmışır. Yanındaki devlet eşyalarını teslim etmesi gerektiği bildirilince, kendisinden 'İzmir'den ayrılmadan evvel eşyaları teslim ettiği, yanında kendi parasıyla satın aldığı kılıçtan başka bir eşyanın bulunmadığı" yönünde bir cevap alınmıştır. Ayrıca bu cevap Ali Rıza Efendi tarafindan yazıya da dökülmüş̧ür. Hem sözlü hem de yazılı cevabı 7 Ekim 1913 tarihinde İskenderiye Muhafızlığından Misır Dahiliye Nezaretine, oradan da 18 Ekim'de Aydın Valiliğine iletilmiştir (BOA, DH. EUM. EMN., 117/28, s. 11; 18 Ekim 1913). Ali Riza Efendi'nin 5 Ekim 1913 tarihli cevap yahut savunma niteliğindeki yazısı şu şekildedir:

\footnotetext{
9 Ayrıca Polis Mecmuası'nın 1914 yılına ait sayılarından birinde Aydın Vilayeti mürettebatından 196 numarada kayıtlı Ali Rıza Efendi isimli bir polis memurunun fotoğrafı meşhur hırsızlardan birisinin yakalanması noktasında gösterdiği başarı öyküsüyle birlikte yayınlanmıştır (bkz. Ek-4). Yukarıda paylaşılan fotoğrafla ekte verilen söz konusu fotoğraf mukayese edildiğinde şahıslar birbirlerine hayli benzemektedir. Ancak tarih ve memuriyet dereceleri itibariyle aralarında bir uyuşma sağlanamamıştır. (Polis Mecmuası 22: 513).
} 
Aydın Vilayeti'nin İskenderiye Muhafızlı̆̆’’na yazmış olduğu tahriratta firarım esnasında beraberimde getirdiğimden bahsedilen mirî eşyanın tümünü İzmir Polis Dairesi’nde Müfettişlik Kalemi’nde Komiser Muavini İhsan'a teslim ettiğimi, kendi paramla satın aldığım ve şu an hanemde bulunan kılıçtan başka mirî eşyaya ait nezdimde herhangi bir eşyanın bulunmadığını cevap olarak yazarım. (BOA, DH. EUM. EMN., 117/28, s. 14).

Ali Rıza'nın cevabına bakılırsa ortada kendisini takip etmeyi gerektirir herhangi bir sebep yoktur. Ancak buna inanmak için onun işaret ettiği Komiser Muavini İhsan Efendi'den durumun sorulması gerekmektedir. Nitekim Aydın Valiliği de öyle yapmış, İskenderiye'den alınan cevap İzmir Polis Müdüriyetine yönlendirilmiştir. Ancak İhsan Efendi'den Ali Rıza'nın takibine bir müddet daha devam edileceğini gösterir şu ses yükselmiştir: "Bana asla öyle bir teslimat yapılmadı!” (BOA, DH. EUM. EMN., 117/28, s. 13; 15 Teşrinievvel 1329/28 Ekim 1913) İhsan Efendi yalan söylüyor olamaz mı? Elbette olabilir, lakin yalanladığı şahıs kendi komiseriyken rüşvet aldığı için meslekten ihraç edilmiş ve Mısır'a kaçmış Ali Rıza Efendi olduğundan doğruluk ibresi şimdilik şüphe götürmez bir biçimde İhsan Efendi'den yanadır.

\section{Merkezî Takip}

İzmir'den alınan cevapla Ali Rıza Efendi'nin peşi bırakılmamış, hatta onu yakalama işi yerel makamlardan imparatorluk merkezindeki birimlere geçmiştir. Bu sayede yürütülen takip ve tahkikatın genişletilmesi mümkün olmuş, Ali Rıza'nın Mısır'daki serüvenine ilişkin yeni bilgiler de ortaya çıkmışıtır. Mesela yapılan araştırmalar neticesinde onun Mısır'da Özbekiye ${ }^{10}$ denilen yerde mülazım-1 evvel Harputlu Şükrü Efendi ile birlikte meyhanecilik etmekte olduğu, hatta o sıralar devlete ait olan revolverini 6 İngiliz lirasına sattığ1 öğrenilmiştir. Gün yüzüne çıkarılan her yeni bilgi ise Ali Rıza hakkındaki şüphe ve ithamları büsbütün artırmıştır. Mesela Emniyet-i Umumiye Müdüriyeti tarafindan Dersaadet Merkez Kumandanlığına gönderilen bir yazıda Ali Rıza için cidden çok zararlı bir adam olduğu düş̈̈ülmektedir (BOA, DH. EUM. EMN., 117/28, s. 16-17.) şeklinde bir ifadeye yer verilmişti. Dolayısıyla öyle tehlikeli birisini sadece basit bir zimmet suçlamasıyla İngiliz denetiminde bulunan Misır idaresinden talep etmek ters ve anlamsız bir tepki doğurabilirdi. Bu riski hesap eden Osmanlı yöneticileri Ali Rıza Efendi'nin daha gerçekçi bir gerekçeyle Osmanlı tarafına iade edilmesi için bir çare düşündüler. Bu doğrultuda Ali Rıza'ya bir asker firarisi süsü verildi. Emniyet Genel Müdürlügünden gelen bildirim üzerine Dersaadet Merkez Kumandanlığı hemen harekete geçti ve Mısır Fevkalade Komiser Vekâletinin kapısını çaldı. Bir asker firarisi olan Ali Rıza Efendi'nin yakalanarak Sultan'in memurlarına teslim edilmesini istedi (BOA, DH. EUM. EMN., 117/28, s. 16-17). Bu isteğe ilişkin olarak hazırlanan yazının eklerinde Ali Rıza'nın yukarıda paylaşılan fiziksel niteliklerini belirten bir not da mevcuttu (BOA, DH. EUM. EMN., 117/28, s. 7).

İstanbul'un talebi üzerine hem Misır'daki birimler hem de Osmanlı özel memurları kanalıyla yeni bir arama çalışması başlatıldı. Bu çalışmalar devam ederken Emniyet-i Umumiye Müdürlüğüne bağlı İstitlaat Müdürlüğ̈̈ ${ }^{11}$ de ismine ve vazifesine uygun olarak Ali Rıza Efendi hakkında başlattığ1 bilgi toplama çalışmalarını aralıksız sürdürmekteydi. Sabık komiserin hem mazisine hem de hâlihazırdaki ahvaline dair bilinenlerin artması bahsedilen çalışmalar sayesinde mümkün olmuştu. İstitlaat Müdürü İsmail imzasiyla 5 Nisan 1914 tarihinde Dahiliye Nezaretine sunulan bir raporda kaydedildiği üzere Ali Rıza Efendi talebeliği sırasındaki kötü hareket ve ahlakından dolayı Harbiye Mektebi'nden kovulmuştu. (Ali Rıza'nın devlet memuriyetindeki en sağlam referanslarından birisi şimdi muhalefete geçtiği için kendisine karşı bir silah olarak kullanılmaktadır). Ama her nasılsa

\footnotetext{
10 Ali Rıza Efendi’nin o devir Mısır’ında meyhanecilik etmiş olması yadırganabilir. Ancak Özbekiye denilen yer eğlence hayatıyla meşhurdur. Hatta 1903 senesinde hafiyelerin takibinden kurtulmak için Mısır'a firar edip 7 yılını orada geçiren Neyzen Tevfik'in de Özbekiye'deki bir saz bahçesinde çalışan orkestraya katılarak ney üflediği ve orada birdenbire üne kavuşmuş olduğu bilinmektedir. Bkz. (Kabacalı, 2003: 21, 23).

11 İstihbarat ve İstitlaat'a ilişkin iş ve işlemlerle ilgilenmek üzere Emniyet-i Umumiye Dairesi'nde bir İstitlaat Müdüriyeti'nin ihdası hakkında 2 maddelik kanun-u muvakkat için bkz. (Polis Mecmuası 12: 280).
} 


\section{YÜKSEL, Ahmet (2020). "İstanbul, Kahire ve Beyrut Üçgeninde Firarî Bir Osmanlı Polisi”, Mavi Atlas, 8(2): 323-342}

sonradan bir yolunu bulup polisliğe intisap etmiş ve nihayet İzmir üçüncü sınıf polis komiserliğine kadar yükselmişti. Meslekten çıkarılınca Mısır’a gidip muhaliflerin safına katılmıştı. Uzunca bir süredir orada bulunmaktaydı. Mısır'daki faaliyetlerine ilişkin olarak da kaynağı Mısır'daki özel memurumuðdan gelen mektuplar olarak belirtilen çok mühim bilgilere ulaş1lmıştı. Mesela söz konusu vesikada isminin önünde "tanıdık, bilindik" anlamındaki mahud sıfatı yer alan ve hakkında başkaca bir bilgiye yer verilmeyen Safvet ${ }^{12}$ isimli birisiyle beraber bir ara Doğu Kürdistan'1 gezmiş ve ardından tekrar Mısır'a dönmüş olduğu bildirilmiştir. Bu pis herif şeklinde devam eden yazıda Ali Rıza Efendi'nin kâh Sadık ve refikleri nezdinde bazen de İskenderiye polis hafiyeliği dairesinde Osmanlı Hükümeti aleyhine akla sı̆̆maz fenalıklar işlediğinden bahsedilmiştir (BOA, DH. KMS., 3/33; DH.EUM.EMN., 117/28, s. 16-17; 23 Mart 1330/5 Nisan 1914).

Raporun devamına geçmeden evvel vesikada ismi zikredilen Sadık ve arkadaşları hakkında kısa bir pasaj oluşturmak gerekiyor. Mısır'ın, o dönem İttihatçılara muhalif olanlar için bir çekim yahut cazibe merkezine dönüştüğünden yukarıda bahsedilmişti. Sadık Bey ve arkadaşları da söz konusu çekime kapılan meşhur muhaliflerdendiler. Miralay unvanıyla zihinlerde yer etmiş olan (Mehmed) Sadık Bey, Manastır mebusuydu. İttihat ve Terakki Partisi'nin demokratik olmayan otoriter tutumuna karşı her geçen gün keskinleşen parti için muhalefetin başlıca simasına dönüşmüştü. Karesi mebusu Abdülaziz Mecdi ile birlikte Hizb-i Cedit (Yeni Oluşum) hareketinin liderliğini yapmıştı. II. Meşrutiyet Devri'nin Meclis-i Mebusanı'ndaki muhalefetin en kuvvetlisi olan Hizb-i Cedit hareketi ilerleyen süreçte meclis içerisinde palazlanıp diğer muhaliflerle birleşerek Aralık 1911'de Hürriyet ve İtilaf Firkasına dönüşmüştü (Yiğit, 2014: 104 vd.). Sadık Bey, doğal olarak firkanın kurucuları arasında yer almış ve ikinci başkanlığını yürütmüştü. Nihayet Balkan bozgununun ardından İttihatçıların Babıâli Baskını (1913) ile iktidarı yeniden ele geçirip bütün muhalefeti yok etme yoluna gitmesi üzerine Misır'a kaçmış ve I. Dünya Savaş1 süresince muhalefetini sürdürmüştür (Birinci, 1998: 509; Demir, 2010: 328; Özdemir, 2016: 127-128).

Miralay Sadık gibi Mısır'da temas kurduğu şahıslar ve yürüttüğü diğer faaliyetler açısından değerlendirilince Ali Rıza Efendi'nin İttihat ve Terakki yönetimi açısından bu kez hakikaten son derece tehlikeli bir adama dönüşmüş olduğunu söylemek kolaylaşıyor. Sözün özü korkulan olmuştur. İstitlaat Müdürü İsmail Bey'in ifadesi olmak üzere "O, kelimenin tam manasıyla sefil bir fesatçıydı.” Üstelik yukarıda bahsedilen raporun devamına bakılacak olursa yürüttüğü muhalif faaliyetler şimdiye kadar sıralananlardan ibaret değildi. Mesela "Aziz Ali Meselesi’ni”’’3 de kendi

\footnotetext{
12 Arşivdeki vesikalara bakılırsa bahsedilen yıllarda Mısır'da bulunup İttihatçılar aleyhine faaliyet gösteren Safvet isimli şahıs Dersaadet merkez eski kumandanıdır. Kendisi vazifeden kovulunca Mısır’a gitmiş ve orada tıpkı Ali Rıza gibi muhaliflerin safina katılarak devlet aleyhinde faaliyet yürütmüş, halkı hükümet aleyhinde tahrik etmiştir. Bu nedenle İstanbul Divan-1 Harb-i Örfisi tarafindan idama mahkûm edilmiş ve görüldüğü yerde yakalanması hususu tüm vilayetlere tebliğ edilmiştir. (BOA, DH. EUM. MTK., 74/60; 4 Safer 1332/2 Ocak 1914; DH. KMS., $3 / 34 ; 19$ Cemaziyülevvel 1332/15 Nisan 1914). Onun, İttihat ve Terakki yönetimine karşı her türlü muhalif hareketin içerisinde yer aldığına iliş̧kin olarak bir hayli arşiv vesikası bulunmaktadır. Mesela Dahiliye Nezareti'nden Hüdavendigar Vilayeti'ne "bizzat açlacak şifre" olarak gönderilen telgrafta, Dersaadet merkez eski kumandanı Safvet Bey'in kamuoyunu hükümet aleyhtarı bir hareket ve fikre sürüklemek için Misır'da bastırdığı beyannameleri bazı kimseler vasıtasıyla Anadolu'da dağıtmakta olduğundan bahsedilmiști. (BOA, DH. SYS., 111/18; 23 Mayıs 1329/5 Haziran 1913). Vilayetlere gönderilen umum bir şifrede ise son posta ile Misır'dan gelen "Bores Ejipsiyen ve Eş-Şa'b" gazetelerinde Dersaadet merkez eski kumandanı Safvet imzasıyla Padişah ile İttihat ve Terakki Cemiyeti liderlerinin aleyhinde bir beyanname bulunduğu anlaşıldığından gerekli takibatın yapılması istenmişti. (BOA, DH. SYS., 111/21; 3 Haziran 1329/16 Haziran 1913).

13 Aziz Ali el-Mısri, 19. yüzyılda Kahire'ye yerleşmiş Basralı bir ailenin çocuğu olarak 1879 senesinde Misır'da doğmuştur. İlköğrenimini tamamladıktan sonra İstanbul'a giderek Mekteb-i Harbiyye-i Şâhâne’ye girmiş ve 1904 senesinde buradan mezun olarak Osmanlı ordusunda görev almıştır. İttihatçılarla okul yıllarında başlayan yakınlığı mezuniyetten sonra artarak devam etmiştir. Enver Paşa aracılığılla Selanik merkezli Osmanlı Hürriyet Cemiyeti’nin Manastır teşkilatına kabul edilmiştir. 31 Mart hareketinin bastırılması için, İstanbul'a gelen Hareket Ordusu'nun bir müfrezesine kumanda etmiştir. Ancak 1909'dan sonra imparatorluk içerisinde özerlik için faaliyet gösteren gizli cemiyetlere girmiș ve el-Kahtaniye ve el-Ahd gibi Arap milliyetçiliği yapan, bir Türk-Arap federasyonu kurmayı
} 
kötü emellerini icra sahasına aktarmak için bir vasıta olarak kullanıp Osmanlı ve Hidiv hükümetlerini birbirine düşürmeye çalışmıstı. Bu amaçla türlü imzalarla sahte telgraflar çekip, nice mektuplar kaleme almıştı. Bütün bu suçlarından ötürü İskenderiye polisi tarafindan takibe alınmış olduğunu anladığından şu günlerde gizli yollardan Beyrut'a bağlı Hayfa'ya geçmek zorunda kalmıştı. Orada Hicaz Demiryolu Kaleminde çalışan ve vaktiyle kendisi gibi Harbiye Mektebi’nden kovulmuş olan Kazım Efendi adındaki bir arkadaşının yanında misafir olarak kalmakta olduğu öğrenilmişti. Hakkında ortaya çıkan bu kadar bilginin ardından Ali Rıza Efendi’nin "cidden pek hileci ve zararlı bir fesatçı" olduğu noktasında şüpheye yer bırakmadığına kanaat getiren İstitlaat Müdürü İsmail Bey onun hemen yakalanıp Dersaadet Divan-1 Harb-i Örfisi'nde yarg1lanabilmesi için acilen Hayfa'da icap edenlere gerekli emrin gönderilmesini Dahiliye Nezaretinden ehemmiyetle talep etmiştir (BOA, DH. KMS., 3/33; DH.EUM.EMN., 117/28, s. 16-17; 23 Mart 1330/5 Nisan 1914).

\section{Beyrut-İstanbul İstihbarat Hatt1}

Bu son bilgiler 1şığında Ali Rıza Efendi artık Mısır'da değil, gerçek anlamda bir Osmanlı vilayeti, ayrıca eski ve biraz da zoraki memuriyet mahalli olan Beyrut'un sınırları içerisindedir. Nitekim Emniyet-i Umumiye Müdüriyeti'nin yukarıda aktarılan talep yazısından bir gün sonra, 6 Nisan 1914 tarihinde Dahiliye Nazırı Talat imzasıyla Beyrut Vilayetine şifreli bir emir gönderilmiş, “fesatçılardan olup Mısır'da Osmanlı Hükümeti aleyhine nice muhalif hareketlere cüret eden” Ali Rıza adındaki şahsın hemen yakalanarak denetim altında ve süratle İstanbul'a gönderilmesi istenmişti. ${ }^{14}$ Beyrut Valisi Bekir Sami Bey, İstanbul'a takdim ettiği 13 Nisan 1914 tarihli cevap yazısında Ali Rıza Efendi'nin Hayfa'ya geçmiş olduğu bilgisini doğruluyordu. Valilik, onun bulunması için vilayet genelinde bir tahkikat başlatmıştı. Neticesinde Ali Rıza'nın Cenin ve Nablus arasında çalışan müteahhitler nezdinde iş aramaya gittiği öğrenilmişti. Firar etmesine meydan verilmeksizin yakalanması için hemen gerekli birimlere tebligatta bulunulmuştu. Dolayısıyla artık onun ele geçirilmesi bir an meselesiydi. Vali Bey, yazısının sonunda sadece herhangi bir pürüz yahut karışıklık yaşanmaması için mümkünse Ali Rıza'nın eşkâl ve hüviyeti hakkında kendilerine bilgi verilmesi yönünde bir talepte bulunmuştu (BOA, DH. KMS, 3/33, s. 5; 31 Mart 1330/13 Nisan 1914; BOA, DH. ŞFR, 423/121).

Beyrut'tan gelen talep aynı gün içerisinde konunun muhatabı olan Emniyet-i Umumiye Müdüriyeti bünyesindeki İstitlaat Müdürlüğune havale edilmiştir. İstenen bilgiler hemen bir gün sonra hazırlanmış ve Beyrut Valiliğinin söz konusu yazısına derkenar yapılmıştır. İstitlaat Müdürü İsmail imzalı bilgiler çalışma içerisinde şu ana kadar paylaşılmış olanların bir derlemesi niteliğinde olup İzmir'de üçüncü sınıf komiserlerindenken efrad-1 redifeden rüşvet alması nedeniyle meslekten atılmasından Mısır'da meyhanecilik etmesine değin yaşadığ1 serüvene ilişkin hemen bütün ayrıntıları kapsamaktadır (BOA, DH. EUM. EMN., 117/28, s. 20). O şekilde hazırlanan rapor aynı gün (14 Nisan 1914) ve "acil şifreli" olarak Nazır Talat imzasıyla Beyrut vilayetine gönderilmiştir (BOA, DH. KMS, 3/33, s. 3; 1 Nisan 1330/14 Nisan 1914; BOA, DH. ŞFR, 40/6).

hedefleyen cemiyetlerin kurulmasında aktif rol almıştır. Nihayet Hidiv'den aldığı parasal destekle büyük bir ayaklanmanın alt yapısını oluşturma gayretinden ve Enver Paşa’ya karşı beslediği düşmanlıktan dolayı tutuklanmıştır. $\mathrm{Bu}$ tutuklanma, Araplarca ondan nefret eden Enver Paşa tarafindan tertip edilmiş bir kurgu olarak değerlendirilmiş, Misır kamuoyunda ve basınında büyük bir tepki doğurmuştur. Serbest birakılması için Misır'da bulunan yandaşları tarafindan İstanbul Divan-1 Harp Başkanlığı'na onlarca teloraf çekilmiștir. Bu arada Aziz Ali, Divan-1 Harp tarafindan idama mahkûm edilmiş, ancak Enver Paşa'nın Padişah katındaki teşebbüsleri neticesinde affedilmiştir. Bu konu hakkında daha fazla bilgi için bkz. (Umar, 2003: 420 vd.; Buzpınar, 2005: 2-3; Sezer, 2018: 60 vd.). Yukarıda aktarılan raporun devamında görüleceği üzere bahsedilen telgraflardan birçoğunun farklı isim ve imzalarla Ali Rıza Efendi tarafindan çekilmiş olduğu kaydedilmiştir.

14 Talat Bey'in bazı hassasiyetleri bu yazıya yansımıştır. Emniyet-i Umumiye Müdüriyeti'nden kendisine sunulan yazıda geçen "Dersaadet" ve "Doğu Kürdistan" tabirlerinin onun kaleminde "İstanbul" ve "Vilayet-i Şarkiye"ye dönüşmesi gibi... (BOA, DH. KMS., 3/33, s. 11; 24 Mart 1330/6 Nisan 1914; BOA, DH. ŞFR., 39/167). 


\section{YÜKSEL, Ahmet (2020). "İstanbul, Kahire ve Beyrut Üçgeninde Firarî Bir Osmanlı Polisi”, Mavi Atlas, 8(2): 323-342}

Beyrut Valiliği kendisine ulaşan Ali Rıza Efendi’nin eşkâli ve faaliyetleri hakkındaki bilgileri ilgili birimlere göndermiş, arama çalışmaları o şekilde sürdürülmüştür. Takvimler 25 Nisan 1914 tarihini gösterdiğinde Beyrut'tan beklenen, ancak beklentilerin uzağında kalan cevap İstanbul'a ulaşmıştır. Çünkü Vali Bekir Sami Bey yapılan araştırmalar neticesinde Ali Rıza Efendi'nin "şimdiki halde" Beyrut'ta bulunmadığını haber vermektedir. Onun sadece iki ay evvel bir defa Beyrut'a geldiğinin, ayrıca Hayfa ve Nablus taraflarında görüldüğünün tespit edildiğini bildirmektedir (BOA, DH. EUM. EMN., 117/28; s. 24; 12 Nisan 1330/25 Nisan 1914; BOA, DH. ŞFR, 424/111). Bu telgrafla sanki Ali Rıza defteri en azından Beyrut cephesinden kapanmış gibidir. Ancak takip eden yazışmalar bunu söylemek için biraz aceleci davranıldığını gösterir türdendir. Çünkü Bekir Sami Bey'den bir öncekine zeyil olarak 2 Mayıs 1914 tarihinde yeni bir telgraf alınmıştır. Telgrafta Ali Rıza hakkında edinilen bazı yeni bilgiler vardır. Mesela onun 21 Mart’ta Beyrut'a geldiği ve iki gün sonra ortadan kaybolduğu saptanmıştır. Ayrıca daha önceleri Trablusşam Komiserliği'nde istihdam edildiği de öğrenilmiştir. Bu bilgileri aktardıktan sonra Bekir Sami Bey bir önceki yazısının aksine Ali Rıza'nın takibine devam edileceğini, "mamafih gizlice araştırılması ve takibi için icap edenlere gerekli uyarılar yapılmıștır" şeklinde yazısının sonuna düşmüş olduğu notla ifade etmiştir (BOA, DH. EUM. EMN., 117/28; s. 26; 19 Nisan 1330/2 May1s 1914).

Sonraki yazışmalar Beyrut Valisi Bekir Sami Bey'in ifadesine sadık kaldığını göstermektedir. Nitekim Beyrut'a bağlı farklı sancaklarda eşzamanlı yürütülmekte olan araştırmalar neticesinde Ali Rıza Efendi hakkında yeni bilgilere ulaşılmakta ve bunlar valilik üzerinden birbiri ardına İstanbul'a sunulmaktadır. Mesela son telgrafin üzerinden henüz bir gün geçmişken Beyrut vilayetinin Nablus sancağına bağlı Cenin Kaymakamlığından yürütülen arama ve takip çalışmalarına ilişkin olarak Beyrut Vilayeti'ne yeni bilgiler ulaşmışır. İlgili yazıda kaydedildiği üzere Cenin Kaymakamlığı, valilikten kendilerine ulaşan emir üzerine hemen kaza jandarma ve polisini harekete geçirerek geniş çaplı bir tahkikat başlatmışır. Bu tahkikata ilişkin olarak Cenin Jandarma Kumandanı Mahmud Celaleddin ve polis memuru Hilmi imzalarıyla 25 Nisan 1914 tarihinde bir rapor hazırlanarak kaymakamlığa takdim edilmiştir. Raporda kaydedildiği üzere, kazanın çeşitli noktalarında gizlice ve derinlemesine araştırmalar yapılmış, ancak Ali Rıza Efendi'nin izine rastlayabilmek katiyen mümkün olamamıştır. Buna karşın tahkikat kapsamında onunla ilgili yeni ve mühim bilgilere ulaşılmıştır. Mesela Ali Rıza Bulgarca ve Rumca ${ }^{15}$ konuşabilmektedir. Kendisine Abdullah adını vererek Hayfa'ya geçmiş, o şekilde Hicaz Demiryolu idaresine girip bir müddet çalıştıktan sonra ilişiğini keserek İstanbul'a gitmiştir. Raporun sonunda "şu hale nazaran Abdullah ismindeki memurun Hayfa'dan ne zaman ayrıldığının ve ayrıldığında nereye gittiğinin öğrenilmesi için durumun ilgili birimden sorulması gerektiğine" dikkat çekilmiştir (BOA, DH. EUM. EMN., 117/28; s. 22; 12 Nisan 1330/25 Nisan 1914). Bu rapor Beyrut Valiliği üzerinden 3 Mayıs 1914 tarihinde Dahiliye Nezareti'ne takdim edilmişti (BOA, DH. EUM. EMN., 117/28; s. 28; 20 Nisan 1330/3 May1s 1914). Cenin polis ve jandarmasınca düzenlenen raporda yer alan bilgi ve tavsiye üzerine Beyrut Valiliği ayrıca Abdullah adıyla oralarda gezindiği haber alınan Ali Rıza Efendi'nin durumunu Akka Sancağı'na bağlı olan Hayfa Kaymakamlığı'ndan sormuştur. Alınan cevapsa aktarılan bilgileri teyit etmektedir: "Evet, Ali Rıza Efendi bir ay evvel İstanbul'a gitmek üzere Hayfa'dan ayrılmıştır." (BOA, DH. ŞFR., 436/3).

Beyrut'tan gelen son bilgiler Osmanlı başkentinde Ali Rıza merkezli bir hareketlilik başlatmıştır. İstitlaat Müdürlüğü hemen Ali Rıza'nın İstanbul'a gelip gelmediğinin anlaşılmasını ve elbette yakalanmasını sağlamak için onun eşkâlini kapsar bir pusula hazırlayıp 20 Mayıs 1914 tarihinde bağlı bulunduğu Emniyet Genel Müdürlüğü’ne takdim etmiş, icap edenlere gereken emrin verilmesini rica etmiştir (BOA, DH. EUM. EMN., 117/28; s. 30; 7 Mayıs 1330/20 May1s 1914).

\footnotetext{
15 Ancak özlük dosyasında Ali Rıza Efendi'nin Türkçe okuma yazmaktan başka farklı dil olarak sadece Almanca konuşabilmekte olduğu kaydedilmiştir (EGM Özlük Dosyaları: C-1557). Aksi yahut yukarıda ifade edildiği gibi olsaydı Ali Rıza o bilginin kayıt altına alınmasını mutlaka sağlardı.
} 
Böylece Osmanlı polis ve hafiyeleri Ali Rıza'nın peşinde yeni bir koşuşturmaca içerisine girmişlerdir. Ancak sarf edilen gayretin neticesi yine o çok bilindik neticeyi vermiştir. Ali Rıza'nın İstanbul'a geldiğini ve şehirde bulunduğunu gösterir herhangi bir ize tesadüf edilememiştir. Hatta onun hala Hicaz Demiryolu'nda çalışmakta olduğu yönünde bir istihbarat sağlanmıştır. Özellikle Ali Rıza'nın hâlihazırda bulunduğu yere dair edinilen bilgiler bir nokta atışı tespit şeklinde değerlendirilmeye müsaittir. Bu durum 22 Temmuz 1914 tarihinde Dahiliye Nezaretinden Beyrut vilayetine gönderilen şifreli bir telgraftan rahatlıkla anlaşılmaktadır. Nitekim burada Ali Rıza'nın mart ayından beri Hicaz Demiryolunun Afule-Kudüs hattının ikinci şubesinde üçüncü kısım inşaatında yevmiyeli geçici işçiler arasında istihdam edildiğinin öğrenildiğine vurgu yapılmıştı. Kendisinin Mısır'da Osmanlı aleyhine casusluk faaliyetine giriştiği anlaşıldığından firarına meydan verilmeksizin yakalanıp denetim altında İstanbul'a gönderilmesi ise yine Beyrut'tan ehemmiyetle talep edilmişti (BOA, DH. ŞFR., 43/88; 9 Temmuz 1330/22 Temmuz 1914).

Buraya kadar aktarılanlardan kestirileceği üzere, Beyrut'tan alınan cevapta herhangi bir değişiklik yoktu. Vilayette Ali Rıza'yı ne gören olmuştu ne de duyan. Zaten o günlerde I. Dünya Savaşı'nın ateşi Osmanlı İmparatorluğu'nu dört bir yandan kuşatmaya başlamıştı. O halde sıradan bir şahısla imparatorluk merkezinin gündemini meşgul etmemek gerekirdi. Yöneticiler o şekilde düşünüp davranmaya çok yaklaşmısken Dahiliye Nezaretine kaynağı belirtilmeyen son bir istihbarat daha geldi. Hem de savaş hengâmesine girildiği 1914 yılının Ekim ayında. Kaynağı meçhul yeni bilgilere bakılırsa Ali Rıza Efendi Hicaz taraflarında yakalanacağını hisseder hissetmez Osmanlı başkentine geçmişti. Buradan ailesini alarak gizlice Ordu kazasının Vona ${ }^{16}$ Nahiyesine gitmişti. Daha ilginç olansa Ali Rıza'nın nahiyede bulunan Ali Paşazade Fuad Bey ${ }^{17}$ vasıtasıyla İstanbul'da yaşayan kayınpederiyle haberleştĭginin de tespit edilmiş olduğundan bahsedilmesiydi. Bu istihbarat üzerine hemen Trabzon Vilayeti'ne Dahiliye Nazırı Talat imzalı şifreli bir telgraf çekildi. Telgraf sanki okuyucu için bir hatırlatma yapmak istercesine Ali Rıza'nın serencamına dair kısa bir aktarımla başlıyordu. Ali Rıza, İzmir'de yürütmekte olduğu polis komiserliği vazifesinden kovulunca resmî elbise ve üzerine zimmetli demirbaş eşyalarla birlikte Kahire'ye firar etmişti. Orada bir müddet Misır Hükümeti için casusluk hizmetinde bulunmuştu. Daha sonra müstear bir isimle (Abdullah) Hicaz Demiryolu'nda çalışmıştı. Şimdi Talat Bey, Trabzon Valisinden Ali Rıza'nın kaçmasına meydan verilmeksizin yakalanıp bütün ailesi ve üzerinden çıkacak evrakla birlikte İstanbul'a gönderilmesini 1srar ve önemle talep ediyordu (BOA, DH. ŞFR., 46/32; 6 Teşrinievvel 1330/19 Ekim 1914). Trabzon'dan nasıl bir cevap alınmıştı? Ali Rıza gerçekten Vona Nahiyesine geçmiş miydi ve yakalanıp İstanbul'a gönderildi mi? Bu sorulara cevap verebilecek vesikalara tesadüf edilememiş olduğundan Ali Rıza'nın hikâyesi şimdilik bu şekilde sona ermektedir.

\section{Değerlendirme}

Ali Rıza'nın İzmir'den Kahire'ye, Özbekiye'den Vilayet-i Şark’a, Beyrut’tan Akka’ya ve bir ihtimal İstanbul'dan Ordu'ya uzanan hikâyesi vesikaların sessizliğe bürünmesiyle birlikte ne şekilde sonlandığ1 bilinmeden bitmiş gibidir. İlerde tespit edilmesi muhtemel yeni vesikalar bu tansiyonu yüksek hikâyenin yarım kalan kısımlarının tamamlanmasını elbette mümkün kılacaktır. Ancak bu kadarıyla bile Ali Rıza Efendi’nin serencamı içerisinde nice ilginçlikler barındırmaktadır. Onun, zamanının insanlarından pek farklı olarak gelişen hareketli yaşantı ve kaçışının yanında bu çalışma

\footnotetext{
16 Vona, Perşembe Nahiyesi'nin eski isimlerindendir. Kelimenin etimolojik kökeni hakkında bkz. (Öztürk, 2005: 1163). 17 (Ali) Fuad Bey, Çürüksulu Ali Paşa'nın oğludur. 1893 yllında Ordu'nun Perşembe Nahiyesi’nde doğmuştur. Okul yılları ve gençliği tamamen İstanbul'da geçmiştir. 1913 yllında Saint Joseph mektebini bitirmiştir. Aynı yıl makina mühendisliği yüksek tahsili görmek amacıyla Berlin’e gitmiş, ancak 1914 senesi Ağustos’unda seferberlik ilanı üzerine apar topar İstanbul'a dönmek zorunda kalmıștır. Bir hafta içerisinde kendisini Teșkilat-1 Mahsusa alayının Karadeniz'deki müstakil taburunda bulmuş, burada bölük kumandanı yapılmıştır. Trabzon istikametine ilerleyen işgalci Rus ordularına karşı kendi memleketi olan Ordu-Perşembe-Fatsa mıntıkasında örgütlenen askerî yapılanmalarda görev almış, özellikle asker firarilerini takip etmekle görevlendirilmişti. Fuad Bey'in hayatı ve söz konusu askerî faaliyetleri hakkında daha fazla bilgi için (Özel, 2003: 121-122; Özel, 2012: 112 vd).
} 
ayrıca Aydın-İzmir özelinde polis teşkilatı mensuplarının suç ile aralarındaki aşırı yakınlaşmaya, İttihat ve Terakki'ye muhalif olanlara kucak açan Misır'ın o dönem kazandığ1 görüntüye ve onlardan da önemlisi bir casusluk zanlısı olan eski ve sıradan bir memurunun peşine düşen Osmanlı karar alıcılarının hedef kişiyi bir güvenlik tehdidi olarak algılamaya başladıkları andan itibaren merkez ve yerelde nasıl organize olabildiklerine ilișkin kesitler sunması bakımından da ilgi çekici bir nitelik arz etmektedir. Gerçekten de I. Dünya Savaşı'nın hemen öncesinde nice problemle çepeçevre kuşatılmış bir imparatorluğu yönetenler açısından Ali Rıza Efendi'nin takip dozunun artırılması onun beraberinde götürdüğü devlete ait eşyaları geri alabilmekten ziyade İngiliz güdümündeki Mısır Hükümeti'ne casusluk etmekte olduğuna, hatta o kapsamda Doğu Anadolu'ya geçtiğine ilişkin şüphelerle daha yakından alakalı olduğu rahatlıkla ifade edilebilir.

\section{Kaynakça}

ALYOT, Halim (2008). Türkiye'de Zabıta, Tarihı̂ Gelişim ve Bugünkü Durum, Ankara: Türk Polis Tarihi Araştırma Merkezi.

ARI, Kemal (2017). “İzmir’in İşgalinde Polis Teşkilatı ve İlk Direniş Çabaları”, Türk Polis Taribinin Kökenleri, ed. Yücel Yiğit, ss. 435-449, Ankara: Polis Akademisi Yayınları.

ARSLAN, Bahar (2008). II. Messutiyet Dönemi'nde Aydn Vilayeti'nde Güvenlik, (Yayımlanmamış Yüksek Lisans Tezi), Ege Üniversitesi Sosyal Bilimler Enstitüsü, İzmir.

BİRINCİ, Ali (2002). “Ahmed Bedevî Kuran, Jön Türklüğün Tarihçisi”, Selçuk Üniversitesi Türkiyat Arasturmalar Dergisi, 12: 1-37.

BİRİNCİ, Ali (1998). "Hürriyet ve İtilâf Fırkası", TDV İslam Ansiklopedisi, Cilt 18, ss. 507511, İstanbul: Türkiye Diyanet Vakfı Yayınları.

BUZPINAR, Şit Tufan (2005). "Misrî, Azîz Ali”, TDV İslam Ansiklopedisi, Cilt 30, s. 2-3, İstanbul: Türkiye Diyanet Vakf1 Yayınları.

DEAL, Roger A. (2017). “A Policeman's Life in Hamidian Istanbul”, Türk Polis Taribinin Kökenleri, ed. Yücel Yiğit, ss. 355-373, Ankara: Polis Akademisi Yayınları.

DEMIR, Halim (2010). Yeraltmdan İktidara Ittihat ve Terakki (Darbeler ve Suikastlar Taribi), İstanbul: Ozan Yayınları.

GÖREN, Hüseyin Hüsnü (2018). Birinci Yüsynlinda (1839-1938) Türk Polis Teşkilatınm Tekamül, Teşkilat ve Kadro Hareketleri, yay. haz. Ebubekir Açıkgöz, Ankara: Emniyet Genel Müdürlüğü Yayınları.

KABACALI, Alpay (2003). Çessitli Yönleriyle Neyz̨en Tevfik (Hayatı-Kişiliüi-Şïrleri), İstanbul: Özgür Yayınları.

LEVY-AKSU, Noémi (2017). Osmanl İstanbulu'nda Asayiş, 1879-1909, İstanbul: İletişim Yayınlar1.

Muallim Naci (1332). Lugat-ı Nâcî, İstanbul: Amire Matbaası.

ÖZCAN, Abdülkadir (2007). "Redif", TDV İslam Ansiklopedisi, Cilt 34, ss. 524-526, İstanbul: Türkiye Diyanet Vakfı Yayınlanı.

ÖZDEMIR, Hüseyin (2016). Demokrasi Taribimižde Itttibâd ve Terakkili Yullar (Babanæâade İsmail Hakkı Bey'in Penceresinden), İstanbul: Ötüken Yayınları.

ÖZEL, Oktay (2003). "Çürüksulu Ali Paşa ve Ailesi Üzerine Biyografik Notlar”, Kebikę̧, 16: 95-144. 
YÜKSEL, Ahmet (2020). “İstanbul, Kahire ve Beyrut Üçgeninde Firarî Bir Osmanlı Polisi”, Mavi Atlas, 8(2): 323-342

ÖZEL, Oktay (2012). “O İnce Çizgi: Osmanlı Son Dönemi Pratiğinde Eşkıyalıkla Kahramanlık Arasında Salınanlar”, Kebikę̧, 34: 107-138.

ÖZKOÇ, Özge (2013). Imparatorluk İktidarnmn Sinurnda Osmanh Misir: Mehmed Ali Paşa Döneminden Hzdivliğe, (Yayımlanmamış Doktora Tezi) Ankara Üniversitesi Sosyal Bilimler Enstitüsü. Yayınlar1.

ÖZTÜRK, Özhan (2005). Karadeniz, Ansiklopedik Sözlïk, Cilt II, İstanbul: Heyamola

POLAT, Ü. Gülsüm (2013). “Milli Mücadele Sürecinde Misır İle Kurulan Bağ ve 'Kemalist Propaganda' Alg1s1”, Akademik Orta Doğu, 8(1): 51-70.

SEZER, Selim (2018). “Arap İsyanından Önce Yaşanan Bir Kriz: Binbaşı Aziz Ali El-Mısri Vakası", Toplumsal Tarih, 294: 60-65.

SÜRGEVIL, Sabri (1984). 1914-1918 Yullar Arasinda Ittihat ve Terakki Furkasinnm İmir Politikası, (Yayımlanmamış Doktora Tezi) Ege Üniversitesi Edebiyat Fakültesi, İzmir.

ŞAHIN, Eyüp (2018). Dersaadet Polis Mektebi, Ankara: Polis Akademisi Yayınları.

UMAR, Ömer Osman (2003). “Aziz Ali El- Misri ve Osmanlı Devleti’ne Karşı Faaliyetleri”, Furat Üniversitesi Sosyal Bilimler Dergisi, Cilt 13, 1: 419-436.

VAN, Nureddin (2012). İstanbul Polis Müdüriyet-i Umûmiyyesi; Kuruluşu, Teşkilâtı ve Faaliyetleri (1909-1918), (Yayımlanmamış Doktora Tezi) Marmara Üniversitesi Türkiyat Araştırmaları Enstitüsü, İstanbul.

YİĞİT, Yücel (2014). “İttihat ve Terakki Fırkası İçinde Parti İçi Muhalefet: Hizb-i Cedit Hareketi” Cağdaş Türkiye Taribi Araşttrmalar Dergisi, 14(28): 103-125.

Arşivler

I. Türkiye Cumhuriyeti Cumhurbaşkanlığ1 Devlet Arşivleri Başkanlığ1 Osmanlı Arşivi

(BOA) Belgeleri (Belgelerin tam künyeleri metin içerisinde verilmiştir.)

Dahiliye Nezareti Emniyet Şubesi

DH. EUM. EMN., 117/28.

Dahiliye Nezareti Emniyet Şubesi Muhasebe Kalemi

DH. EUM. MH., 122/71.

Dahiliye Nezareti Emniyet Şubesi Muhaberat ve Tensikat Müdüriyeti

DH. EUM. MTK., 74/60.

Dahiliye Nezareti Kalemi Mahsus

DH. KMS, 3/33.

DH. KMS., 3/34.

Dahiliye Nezareti Siyasi Kısım

DH. SYS., 111/18.

DH. SYS., 111/21

Dahiliye Nezareti Şifre Kalemi

DH. ŞFR., 39/167. 
YÜKSEL, Ahmet (2020). “İstanbul, Kahire ve Beyrut Üçgeninde Firarî Bir Osmanlı Polisi”, Mavi Atlas, 8(2): 323-342

DH. ŞFR, $40 / 6$.

DH. ŞFR, 423/121.

DH. ŞFR, 424/111.

DH. ŞFR., $43 / 88$.

DH. ŞFR., 436/3.

DH. ŞFR., 46/32.

II. Emniyet Genel Müdürlüğü Personel Dairesi Başkanlığı Özlük Dosyaları Arşivi C-1557.

III. Salname, Resmî ve Süreli Yayınlar

Salname-i Vilayet-i Aydm, Defa 25, H. 1326/M. 1908.

Düstur, Tertib-i Evvel, c. 8.

Düstur, Tertib-i Sani, c. 5.

Polis Mecmuası, Sy. 12, 1 Kanunusani 1329 (14 Ocak 1914).

Polis Mecmuası, Sy. 13, 15 Kanunusani 1329 (28 Ocak 1914).

Polis Mecmuast, Sy. 16, 1 Mart 1330 (14 Mart 1914).

Polis Mecmuasi, Sy. 22, 1 Haziran 1330 (14 Haziran 1914). 
YÜKSEL, Ahmet (2020). “İstanbul, Kahire ve Beyrut Üçgeninde Firarî Bir Osmanlı Polisi”, Mavi Atlas, 8(2): 323-342

Ekler:

Ek-1: Ali Rıza Efendi’nin Sicil Varakası (EGM Özlük Dosyaları: C-1557).

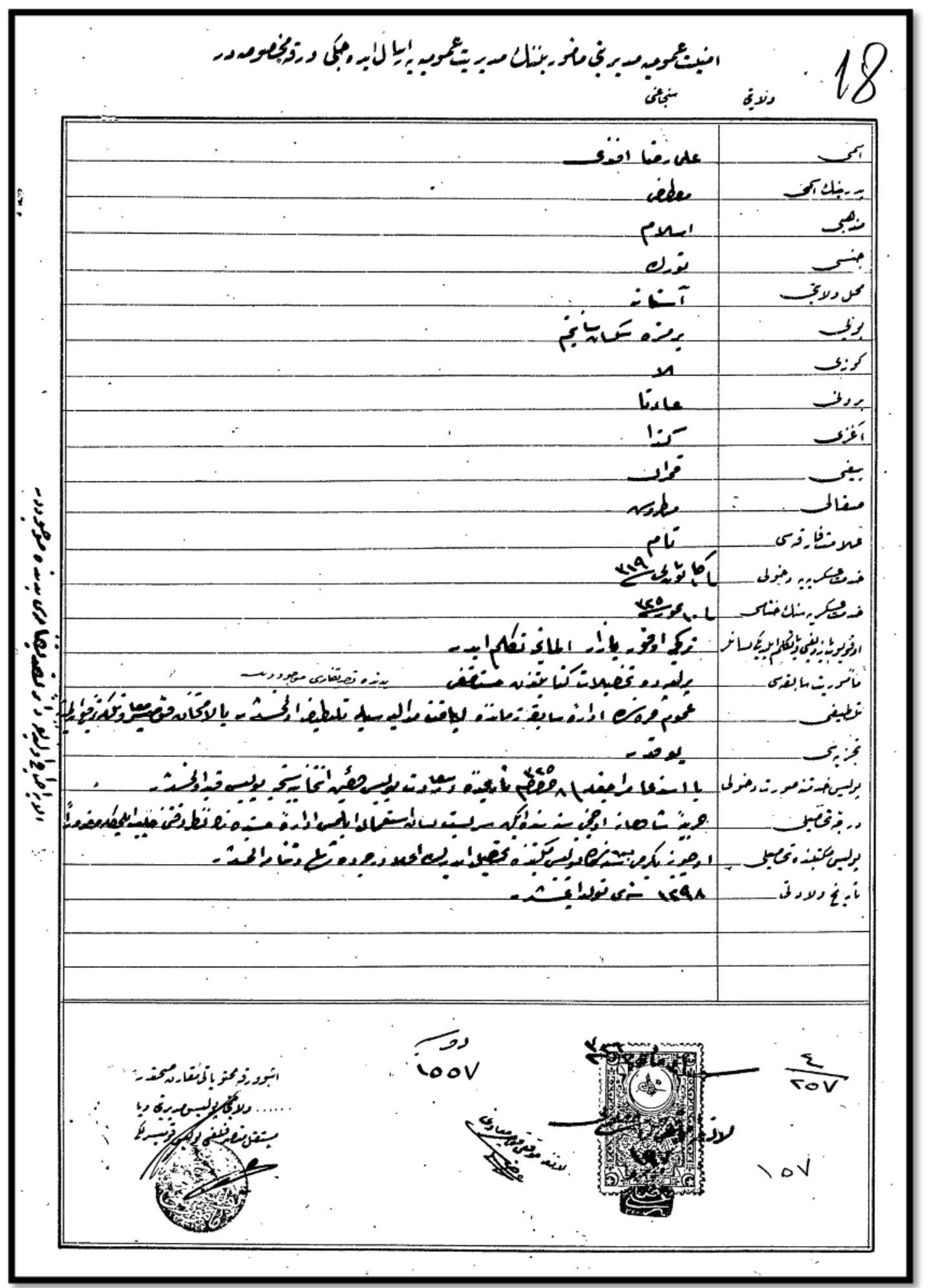


YÜKSEL, Ahmet (2020). “İstanbul, Kahire ve Beyrut Üçgeninde Firarî Bir Osmanlı Polisi”, Mavi Atlas, 8(2): 323-342

Ek-2: Ali Rıza'nın Yakalanması İçin Emniyet-i Umumiye İstitlaat Müdüriyeti Tarafından Oluşturulmuş Rapor. (DH. EUM. EMN., 117/28).

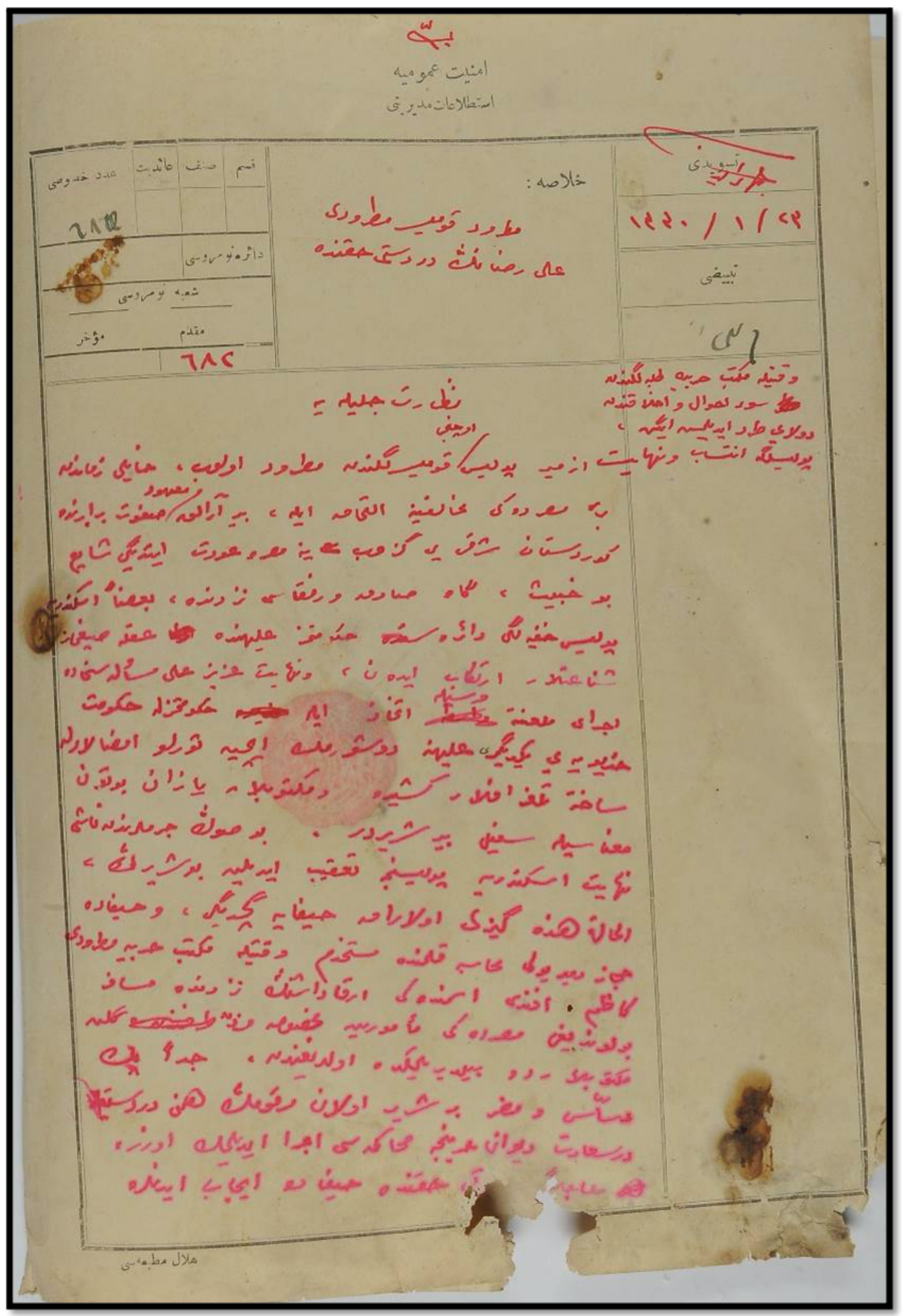


YÜKSEL, Ahmet (2020). “İstanbul, Kahire ve Beyrut Üçgeninde Firarî Bir Osmanlı Polisi”, Mavi Atlas, 8(2): 323-342

Ek-3: Ali Rıza hakkında yürütülen istihbarat çalışmaları neticesinde edinilen bilgilere dair Beyrut valisi Bekir Sami Bey tarafindan gönderilen şifre. (BOA, DH. ŞFR, 423/121).

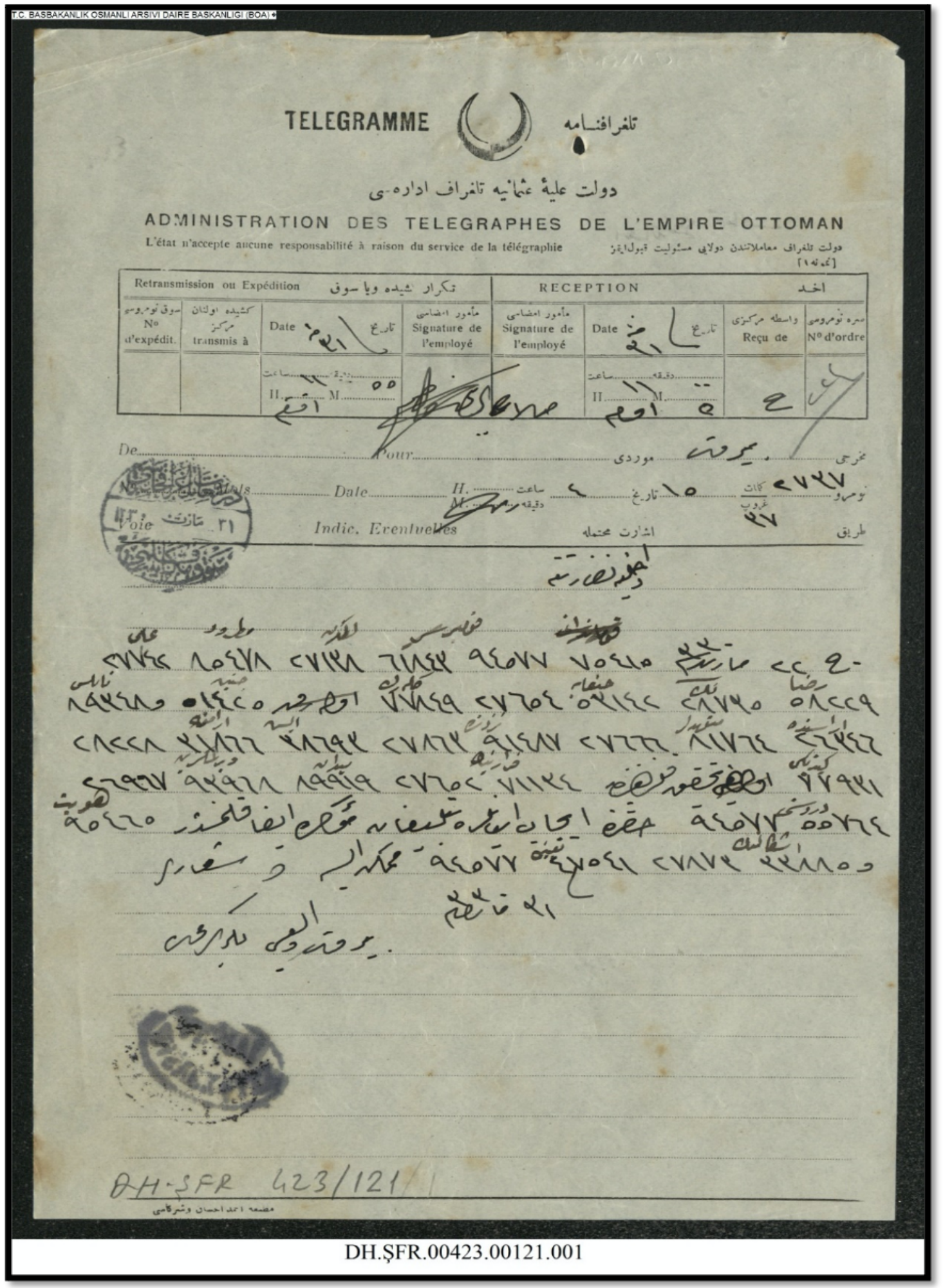


YÜKSEL, Ahmet (2020). “İstanbul, Kahire ve Beyrut Üçgeninde Firarî Bir Osmanlı Polisi”, Mavi Atlas, 8(2): 323-342

Ek-4: Fiziki açıdan bu araştırmaya konu olan Ali Rıza Efendi'ye benzeyen, ancak tarih ve memuriyet dereceleri itibariyle aralarında bağlantı kurulamayan Polis Ali Rıza'nın fotoğrafı.

(Polis Mecmuası 22: 513)

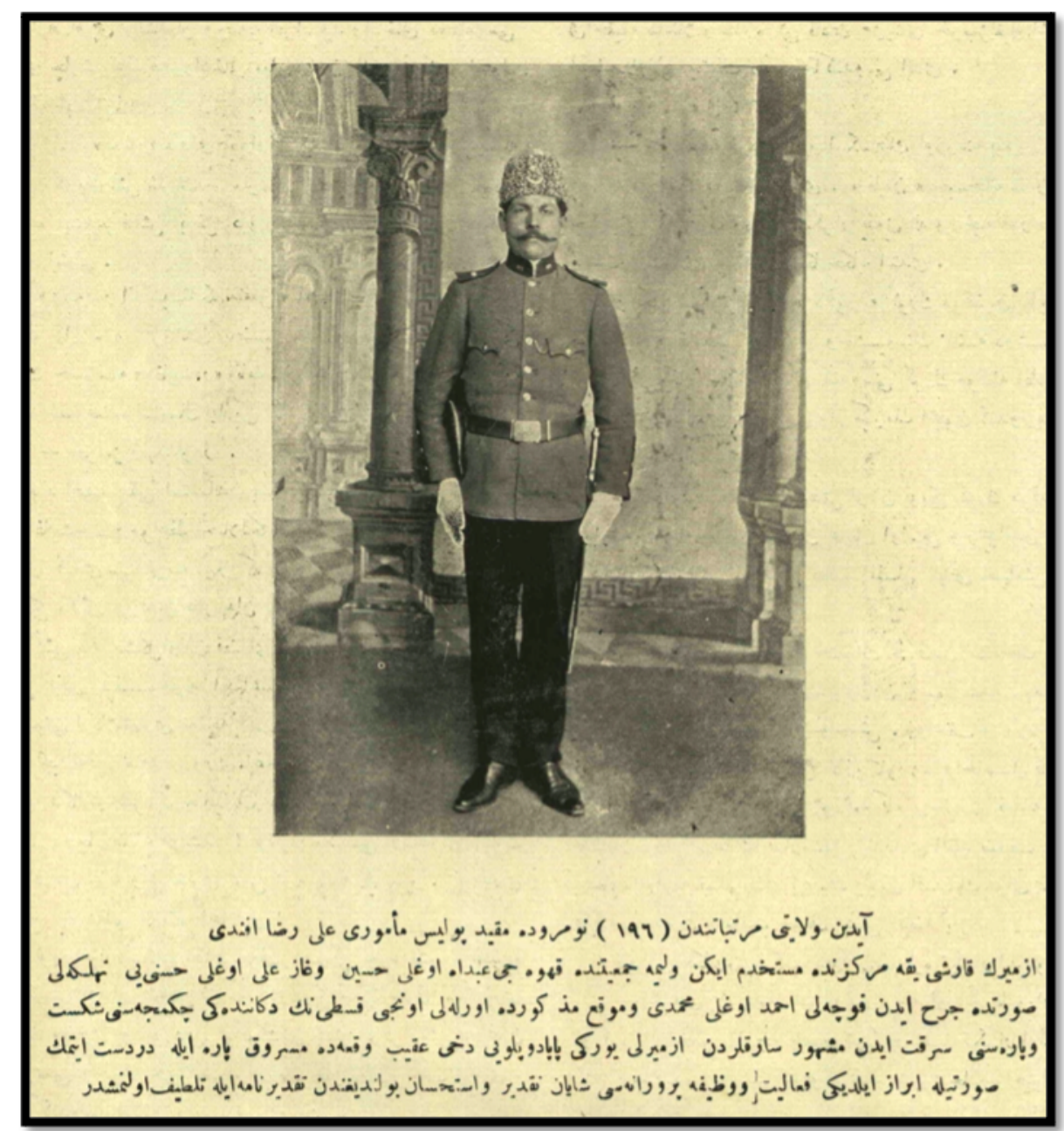

